\title{
Concentrations, particle-size distributions, and dry deposition fluxes of aerosol trace elements over the Antarctic Peninsula in austral
} summer

\author{
Songyun Fan ${ }^{1}$, Yuan Gao ${ }^{1}$, Robert M. Sherrell ${ }^{2}$, Shun $\mathrm{Yu}^{1}$, and Kaixuan $\mathrm{Bu}^{2}$ \\ ${ }^{1}$ Department of Earth and Environmental Sciences, Rutgers University, Newark, NJ 07102, USA \\ ${ }^{2}$ Department of Marine and Coastal Sciences, Rutgers University, New Brunswick, NJ 08901, USA
}

Correspondence: Yuan Gao (yuangaoh@ @ewark.rutgers.edu)

Received: 1 July 2020 - Discussion started: 26 August 2020

Revised: 3 December 2020 - Accepted: 8 December 2020 - Published: 12 February 2021

\begin{abstract}
Size-segregated particulate air samples were collected during the austral summer of 2016-2017 at Palmer Station on Anvers Island, western Antarctic Peninsula, to characterize trace elements in aerosols. Trace elements in aerosol samples - including $\mathrm{Al}, \mathrm{P}, \mathrm{Ca}, \mathrm{Ti}, \mathrm{V}, \mathrm{Mn}, \mathrm{Ni}, \mathrm{Cu}$, $\mathrm{Zn}, \mathrm{Ce}$, and $\mathrm{Pb}$ - were determined by total digestion and a sector field inductively coupled plasma mass spectrometer (SF-ICP-MS). The crustal enrichment factors $\left(\mathrm{EF}_{\text {crust }}\right)$ and $k$-means clustering results of particle-size distributions show that these elements are derived primarily from three sources: (1) regional crustal emissions, including possible resuspension of soils containing biogenic P, (2) long-range transport, and (3) sea salt. Elements derived from crustal sources (Al, $\mathrm{P}, \mathrm{Ti}, \mathrm{V}, \mathrm{Mn}, \mathrm{Ce}$ ) with $\mathrm{EF}_{\text {crust }}<10$ were dominated by the coarse-mode particles $(>1.8 \mu \mathrm{m})$ and peaked around $4.4 \mu \mathrm{m}$ in diameter, reflecting the regional contributions. Non-crustal elements $(\mathrm{Ca}, \mathrm{Ni}, \mathrm{Cu}, \mathrm{Zn}, \mathrm{Pb})$ showed $\mathrm{EF}_{\text {crust }}>10$. Aerosol $\mathrm{Pb}$ was primarily dominated by fine-mode particles, peaking at $0.14-0.25 \mu \mathrm{m}$, and likely was impacted by air masses from southern South America based on air mass back trajectories. However, $\mathrm{Ni}, \mathrm{Cu}$, and $\mathrm{Zn}$ were not detectable in most size fractions and did not present clear size patterns. Sea-salt elements $\left(\mathrm{Ca}, \mathrm{Na}^{+}, \mathrm{K}^{+}\right)$showed a single-mode distribution and peaked at $2.5-4.4 \mu \mathrm{m}$. The estimated dry deposition fluxes of mineral dust for the austral summer, based on the particle-size distributions of $\mathrm{Al}$ measured at Palmer Station, ranged from 0.65 to $28 \mathrm{mg} \mathrm{m}^{-2} \mathrm{yr}^{-1}$ with a mean of $5.5 \pm 5.0 \mathrm{mg} \mathrm{m}^{-2} \mathrm{yr}^{-1}$. The estimated dry deposition fluxes of the target trace elements in this study were lower than most fluxes reported previously for coastal Antarctica and suggest that atmospheric input of trace elements through dry depo-
\end{abstract}

sition processes may play a minor role in determining trace element concentrations in surface seawater over the continental shelf of the western Antarctic Peninsula.

\section{Introduction}

Aerosols affect the climate through direct and indirect radiative forcing (Kaufman et al., 2002). The extent of such forcing depends on both physical and chemical properties of aerosols, including particle size and chemical composition (Pilinis et al., 1995). Size and chemical composition of aerosols influence aerosol optical properties as well as cloud formation and development (Weinzierl et al., 2017), and such information is critically needed in a climate model for better estimating aerosol climate effects (Adebiyi and Kok, 2020). In the atmosphere, the removal of aerosols involves gravitational settling, impaction, diffusion, hygroscopic growth, and scavenging by precipitation, and the rates of all these processes are dependent on the aerosol particle size (Saltzman, 2009). Over the Southern Ocean and Antarctica, aerosol particle-size distributions have been studied (Gras, 1995; Järvinen et al., 2013; Xu et al., 2013; Kim et al., 2017; Herenz et al., 2019; Lachlan-Cope et al., 2020). Seasonal variations of the particle number concentrations were observed at King Sejong Station, Antarctic Peninsula, and Halley Research Station on the Brunt Ice Shelf. The maximum and minimum of the particle number concentrations at two sites were found in the austral summer and austral winter, respectively (Kim et al., 2017; Lachlan-Cope et al., 2020). Due to the low background concentrations of aerosol particles, 
new particle formation has been suggested to substantially affect the annual aerosol concentration cycles (Lachlan-Cope et al., 2020). However, most of these studies focused on the physical characteristics of aerosol particle size; the size distributions of aerosol trace elements are still poorly understood, and at present only aerosol Fe has been characterized for particle-size distributions around Antarctica (Gao et al., 2013, 2020).

Atmospheric aerosol deposition delivers nutrient elements to the open ocean, playing an essential role in maintaining marine primary production (Jickells and Moore, 2015; Jickells et al., 2016; Mahowald et al., 2018). A significant source of atmospheric trace elements in the remote oceans is continental dust derived from arid and unvegetated regions (Duce and Tindale, 1991). In addition, sea-salt emission, volcanic eruptions, biomass burning, anthropogenic activities, and even glacial processes contribute trace elements to the atmosphere (Pacyna and Pacyna, 2001; Chuang et al., 2005; Guieu et al., 2005; Crusius et al., 2011; Baker et al., 2020). The surface concentrations of the trace elements $\mathrm{Al}, \mathrm{Fe}, \mathrm{Mn}$, $\mathrm{Zn}$, and $\mathrm{Pb}$ in several open-ocean regions depend strongly on atmospheric inputs (Duce et al., 1991; Prospero et al., 1996; Wu and Boyle, 1997; Measures and Vink, 2000; Moore et al., 2013; Bridgestock et al., 2016).

Atmospheric trace elements over the Southern Ocean and Antarctica may derive from distant continental sources through long-range transport ( $\mathrm{Li}$ et al., 2008) and local dust sources in certain areas (Kavan et al., 2018; Delmonte et al., 2020). A wide range of aerosol studies have been carried out in Antarctica, with the intention of understanding the processes affecting aerosols and the background level of trace elements in the atmosphere (Zoller et al., 1974; Dick and Peel, 1985; Tuncel et al., 1989; Artaxo et al., 1990; Lambert et al., 1990; Dick, 1991; Artaxo et al., 1992; Loureiro et al., 1992; Mouri et al., 1997; Mishra et al., 2004; Arimoto et al., 2008; Gao et al., 2013; Xu and Gao, 2014; Winton et al., 2016). In the Antarctic Peninsula, the concentrations of aerosol trace elements were measured at several sites (Dick, 1991; Artaxo et al., 1992; Mishra et al., 2004; Préndez et al., 2009). Total dust deposition in this region was also estimated based on the ice-core record (McConnell et al., 2007). However, the measurement of particle-size distribution of aerosol trace elements in the Antarctic Peninsula is missing and there is no direct measurement that evaluated the importance of atmospheric deposition as a source of nutrients for primary producers in western Antarctic Peninsula shelf waters. Over the past several decades, one of the most dramatically warming regions in the Southern Hemisphere has been the Antarctic Peninsula (Vaughan et al., 2003; Bromwich et al., 2013; Turner et al., 2014). Warming ocean waters have caused most glaciers on the peninsula to retreat (Cook et al., 2016), and small increases in air temperature are contributing to rapid summer melting and ice loss in this region (Abram et al., 2013).
Under conditions of low precipitation (Van Lipzig et al., 2004) and high wind speed (Orr et al., 2008), several ice-free areas on James Ross Island, off the east coast of the northern peninsula, could serve as local dust sources (Kavan et al., 2018), and such sources may contribute to the atmospheric loading of certain trace elements such as Fe (Winton et al., 2014; Gao et al., 2020). Similar ice-free areas were found on King George Island, Livingston Island, Anvers Island, etc. in the Antarctic Peninsula region (Bockheim et al., 2013) and may act as potential sources of eolian dust. As part of the current study, the particle-size distribution of aerosol Fe measured at Palmer Station showed single-mode distribution and was dominated by coarse particles, suggesting that local regional dust emission dominated the concentration of $\mathrm{Fe}$ in this region (Gao et al., 2020). Under the current warming trend, ice core data show that lithogenic dust deposition more than doubled during the 20th century in the Antarctic Peninsula (McConnell et al., 2007). In addition, the rapid-warming condition may enhance the emission of other sources. For example, the Antarctic Peninsula has been suggested as one of the sites that have the highest $\mathrm{P}$ excretions contributed by seabird colonies globally (Otero et al., 2018). The enhanced local dust emission may thus cause an increased $\mathrm{P}$ emission as well. Consequently, dust emissions induced by regional warming may have impacted the concentrations of aerosol trace elements in the marine atmosphere over the Antarctic Peninsula, affecting atmospheric deposition of trace elements to coastal waters off the Antarctic Peninsula and adjacent pelagic waters of the Southern Ocean (Wagener et al., 2008). However, aerosol trace elements are still undersampled around coastal Antarctica, and thus quantification of the chemical and physical properties of aerosols and accurate estimation of the atmospheric deposition of trace elements to the region are inadequate.

This study presents multi-element results from an in situ measurement of size-segregated aerosol particles at Palmer Station, Antarctic Peninsula, in the austral summer of 20162017. The objectives are to (1) measure the concentrations and size distributions of a suite of aerosol trace elements, (2) determine potential sources of the elements, and (3) estimate dry deposition fluxes of the elements based on the concentrations in 10 size classes of aerosols. Results from this study fill a data gap critically needed for characterization of aerosol properties and for improving quantification of the fluxes that contribute to regional biogeochemical cycles. The new observational data also provide insight into sources of aerosol trace elements, as influenced recently by warming, which exposes a greater area of ice-free land, and by the impact of human activities in this region. A full discussion of atmospheric $\mathrm{Fe}$ in this sample set was published recently (Gao et al., 2020); this paper extends that study by investigating the concentrations, size distributions, and dry deposition fluxes of a suite of additional aerosol trace elements. 


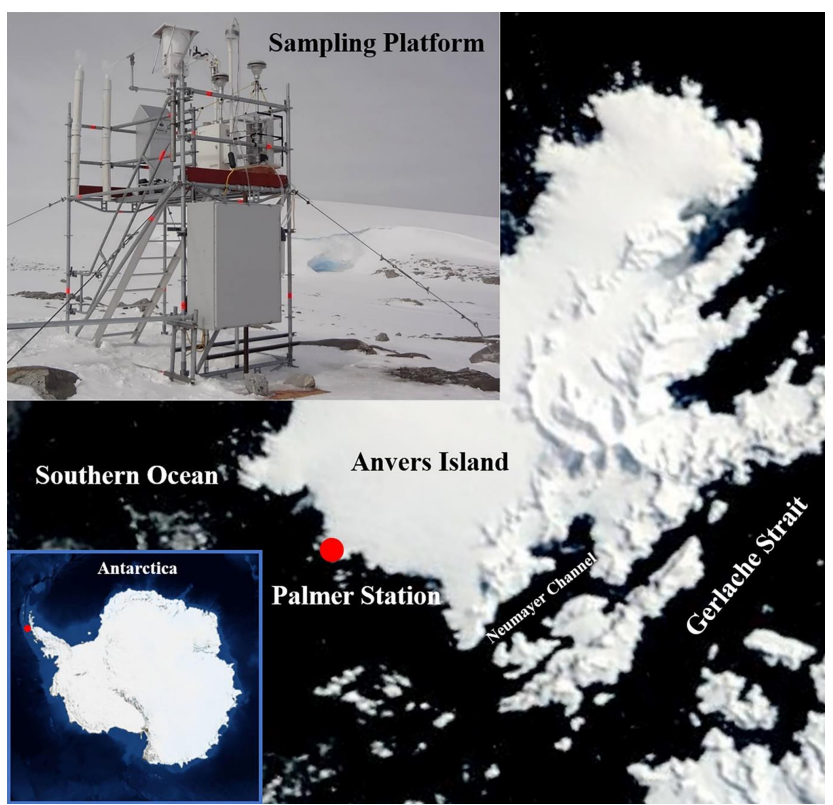

Figure 1. Sampling site at Palmer Station (red dot) with inset photograph of sampling platform (Gao et al., 2020) (satellite image credits: NASA).

\section{Methods}

\subsection{Sampling and sample treatment}

Size-segregated aerosol samples were collected during austral summer from 19 November 2016 to 30 January 2017 at Palmer Station $\left(64.77^{\circ} \mathrm{S}, 64.05^{\circ} \mathrm{W}\right.$, Fig. 1), located on the southwestern coast of Anvers Island off the Antarctica Peninsula. A detailed description of the aerosol sampling, including the protocols for mitigating contamination in the pristine environment, can be found in Gao et al. (2020). Briefly, sampling was conducted using a 10-stage Micro-Orifice Uniform Deposit Impactor ${ }^{\mathrm{TM}}$ (MOUDI, MSP Corp., MN, USA) with a $30 \mathrm{~L} \mathrm{~min}^{-1}$ flow rate. The $50 \%$ cut-off aerodynamic diameters of MOUDI are 0.056, 0.10, 0.18, 0.32, 0.56, 1.0, 1.8, $3.2,5.6,10$, and $18 \mu \mathrm{m}$. In this study, size fractions $\leq 1.0 \mu \mathrm{m}$ were summed to operationally define fine-mode particles, and those $\geq 1.8 \mu \mathrm{m}$ were summed to define coarse-mode particles, similar to previous studies which operationally divided aerosol particles into fine and coarse fractions using a cutoff size of 1.0-3.0 $\mu \mathrm{m}$ (Siefert et al., 1999; Chen and Siefert, 2004; Buck et al., 2010; Gao et al., 2019). The aerosol sampler was placed on a sampling platform which was $\sim 300 \mathrm{~m}$ east from the station center and $\sim 3 \mathrm{~m}$ above the ground ( $\sim 20 \mathrm{~m}$ above sea level) in "Palmer's backyard" (Gao et al., 2020). To avoid local contamination from the research station, a wind control system was set up to pause aerosol sampling when the wind direction was inside the sector $\pm 60^{\circ}$ from the direction of the station buildings or when wind speed was $<2 \mathrm{~m} \mathrm{~s}^{-1}$. The active sampling time was about
$71-98 \%$ of the total sampling time (Table 1). Due to extremely low concentrations of aerosol trace elements over Antarctica, the duration of each sampling event was approximately 1 week (Table 1 ).

After each sampling, the MOUDI sampler was carried back to the lab in the research station for sample filter changing and sampler cleaning in a Class 100 clean-room flow bench. Aerosol samples were stored frozen in pre-cleaned Petri dishes at $-20^{\circ}$ before analyses. A total of eight sets of size-segregated aerosol samples were collected on Teflon filters ( $1 \mu \mathrm{m}$ pore size, $47 \mathrm{~mm}$ diameter, Pall Corp., NY, USA). A full set of blank filters $(n=11)$ was mounted on the sampler, carried to the sampling platform without running the sampler, and thus defined as field blanks. Meteorological conditions were recorded in situ by a weather station (Campbell Scientific, UT, USA) installed on the same platform (Table 1).

\subsection{Chemical analyses}

\subsubsection{Trace elements in aerosols}

Aerosol samples were analyzed for the concentrations of trace elements by an Element-1 sector field inductively coupled plasma mass spectrometer (SF-ICP-MS, ThermoFinnigan, Bremen, Germany) at the Department of Marine and Coastal Sciences of Rutgers University, following a strong acid digestion method described in Gao et al. (2020). Elemental concentrations were determined for $\mathrm{Al}, \mathrm{P}, \mathrm{Ca}, \mathrm{Ti}$, $\mathrm{V}, \mathrm{Mn}, \mathrm{Ni}, \mathrm{Cu}, \mathrm{Zn}, \mathrm{Ce}$, and $\mathrm{Pb}$. Briefly, a quarter of each sample filter was digested in a closed $15 \mathrm{~mL}$ Teflon vial (Savillex, MN, USA) with Optima grade $\mathrm{HF}(0.1 \mathrm{~mL})$ and $\mathrm{HNO}_{3}$ $(0.8 \mathrm{~mL})$ (Fisher Scientific, NJ, USA). Sample digestion was performed on a uniform-heating HPX-200 (Savillex, MN, USA) hot plate for $4 \mathrm{~h}$ at $165^{\circ}$ followed by complete evaporation of acids. Then, $2.0 \mathrm{~mL}$ of $3 \% \mathrm{HNO}_{3}$ with $1 \mathrm{ppb}$ indium (In) solution was added to re-dissolve the sample, with the In used as an internal standard to correct instrument drift in the ICP-MS analyses. All the digestion processes were carried out in a HEPA-filter-controlled Class 100 clean hood in the Atmospheric Chemistry Laboratory at Rutgers University. The Teflon vials and test tubes used in this study were thoroughly acid-cleaned. To ensure the data quality, for each batch of samples, at least two procedural blanks were processed in the same way as the samples to monitor for possible contamination. During the ICP-MS analysis, duplicate injections of sample solutions were made every 10 samples to check the instrument precision (Table S1 in Supplement). The recovery of this analytical protocol was estimated by seven separate digestions of the Standard Reference Material (SRM) 1648a urban particulate matter (National Institute of Standard and Technology, MD, USA) (Table S1). The method limits of detection (LOD) were calculated as 3 times the standard deviation of 11 field blanks and a $200 \mathrm{~m}^{3}$ representative sampling volume (Table S1). The medians of 
Table 1. Sampling periods and meteorological conditions for individual samples (Gao et al., 2020).

\begin{tabular}{|c|c|c|c|c|c|c|c|c|c|}
\hline $\begin{array}{l}\text { Sample } \\
\text { ID }\end{array}$ & Sampling period & $\begin{array}{r}\% \text { Actual } \\
\text { sampling time* } \\
(\%)\end{array}$ & $\begin{array}{r}\text { Sampling } \\
\text { volume } \\
\left(\mathrm{m}^{3}\right)\end{array}$ & $\begin{array}{r}\text { Wind } \\
\text { speed } \\
\left(\mathrm{m} \mathrm{s}^{-1}\right)\end{array}$ & $\begin{array}{r}\text { Air } \\
\text { temperature } \\
\left({ }^{\circ} \mathrm{C}\right)\end{array}$ & $\begin{array}{r}\text { Relative } \\
\text { humidity } \\
(\%)\end{array}$ & $\begin{array}{r}\text { Air } \\
\text { pressure } \\
(\mathrm{hPa})\end{array}$ & $\begin{array}{r}\text { Precip. } \\
\left(\mathrm{mm} \mathrm{d}^{-1}\right)\end{array}$ & $\begin{array}{r}\text { Solar } \\
\text { intensity } \\
\left(\mathrm{W} \mathrm{m}^{-2}\right)\end{array}$ \\
\hline M1 & 19-26 Nov 2016 & 78 & 225 & $5.7(0.7-22)$ & $0.1(-2.2-4.3)$ & $87(52-100)$ & $990(976-1011)$ & 4.19 & $166(0-675)$ \\
\hline M2 & 26 Nov-4 Dec 2016 & 71 & 233 & $4.9(0.4-21)$ & $0.7(-2.2-5.8)$ & $82(45-100)$ & 982 (959-997) & 1.37 & $191(0-847)$ \\
\hline M4 & 9-17 Dec 2016 & 80 & 266 & $3.5(0.1-15)$ & $0.7(-3.3-5.6)$ & $83(53-100)$ & 985 (969-998) & 0.37 & $207(1-854)$ \\
\hline M5 & 17-24 Dec 2016 & 88 & 264 & $2.5(0.3-9.8)$ & $2.0(-0.7-5.5)$ & $77(49-100)$ & 988 (972-996) & 0.05 & $195(1-723)$ \\
\hline M7 & 1-8 Jan 2017 & 85 & 244 & $4.1(0.2-13)$ & $1.8(-0.7-3.8)$ & 72 (49-99) & 987 (972-997) & 0.09 & $272(0-857)$ \\
\hline M8 & 8-15 Jan 2017 & 94 & 283 & $5.4(0.7-16)$ & $2.6(0.3-5.5)$ & $64(46-95)$ & $982(973-991)$ & 0 & $225(0-792)$ \\
\hline M9 & 15-23 Jan 2017 & 87 & 285 & $5.0(0.2-15)$ & $2.1(-1.0-5.3)$ & $65(42-86)$ & 987 (981-997) & 0.15 & $260(0-829)$ \\
\hline M10 & 23-30 Jan 2017 & 98 & 279 & $8.9(0.7-21)$ & $4.1(1.7-7.1)$ & $79(65-90)$ & 981 (969-997) & 3.7 & $110(0-594)$ \\
\hline
\end{tabular}

* Actual sampling time / total sampling time $\times 100 \%$.

the percentage of blanks in samples for detectable trace elements were calculated for quality control (Table S1). The concentrations below LOD were given a concentration of 0 for the purposes of this study. Elements with all concentrations lower than the LOD - including $\mathrm{Cr}, \mathrm{Co}, \mathrm{Cd}$ and $\mathrm{Sb}-$ were measured but are not reported or discussed. The aerosol Fe concentrations were reported in Gao et al. (2020) and are not included in this paper. Although the fractional solubility of Fe was obtained, the solubilities for the other trace elements are not measured or discussed in this study.

\subsubsection{Ionic tracers in aerosols}

The concentrations of water-soluble $\mathrm{Na}^{+}$and $\mathrm{K}^{+}$in aerosols were analyzed by ion chromatography (IC) (ICS-2000, Dionex, CA, USA) with an IonPac CS12A $\left(2 \times 250 \mathrm{~mm}^{2}\right)$ analytical column at the Atmospheric Chemistry Laboratory at Rutgers University. The cations $\mathrm{Na}^{+}$and $\mathrm{K}^{+}$were used as tracers to estimate the portion of aerosols derived from seawater and biomass burning, respectively. The non-seasalt $\mathrm{K}^{+}\left(\mathrm{nss}^{+} \mathrm{K}^{+}\right)$was estimated using the equation [nss$\left.\mathrm{K}^{+}\right]=\left[\mathrm{K}^{+}\right]-0.037\left[\mathrm{Na}^{+}\right]$. Sample processing for IC analysis was similar to the method used by Zhao and Gao (2008) and $\mathrm{Xu}$ et al. (2013). Briefly, a quarter of the sample filter was transferred to a plastic test tube and leached with $5.0 \mathrm{~mL}$ Milli-Q water in an ultrasonic bath for $20 \mathrm{~min}$ at room temperature. Before being injected into the $\mathrm{IC}$, the leachate was filtered through a PTFE syringe filter $(0.45 \mu \mathrm{m}$ pore size, VWR, PA, USA). The method LOD for $\mathrm{Na}^{+}$and $\mathrm{K}^{+}$based on seven blanks and a $200 \mathrm{~m}^{3}$ representative sampling volume was 2 and $1 \mathrm{ng} \mathrm{m}^{-3}$, respectively. The precision of the analytical procedures based on seven spiked samples was $< \pm 1 \%$.

\subsection{Data analyses}

\subsubsection{Enrichment factors}

To achieve an initial estimate of the possible sources for trace elements, enrichment factors relative to the upper continental crust $\left(\mathrm{EF}_{\text {crust }}\right)$ were calculated, using the equation

$\mathrm{EF}_{\text {crust }}=\frac{\left(X_{i} / X_{\mathrm{Al}}\right)_{\text {sample }}}{\left(X_{i} / X_{\mathrm{Al}}\right)_{\text {crust }}}$,

where $\left(X_{i} / X_{\mathrm{Al}}\right)_{\text {sample }}$ is the mass concentration ratio of element $i$ to the crustal reference element, $\mathrm{Al}$, in aerosol samples, and $\left(X_{i} / X_{\mathrm{Al}}\right)_{\text {crust }}$ is the abundance ratio of element $i$ to $\mathrm{Al}$ in the upper continental crust (Taylor and McLennan, 1995). The crustal reference element Al has been widely used to calculate crustal enrichment factors in the Southern Ocean and Antarctica (Zoller et al., 1974; Dick, 1991; Lowenthal et al., 2000; $\mathrm{Xu}$ and Gao, 2014). When the $\mathrm{EF}_{\text {crust }}$ is greater than 10, the element likely has additional contributions from other sources (Weller et al., 2008).

\subsubsection{Particle-size distribution and $k$-means clustering}

The aerosol particle-size distributions were converted to normalized concentrations, which are defined as the concentration of trace elements in a size bin divided by the width of the bin (Warneck, 1988):

$\frac{\mathrm{d} C}{\mathrm{~d} \log \left(D_{\mathrm{p}}\right)}=\frac{\mathrm{d} C}{\log \left(D_{\mathrm{p}, \mathrm{u}}\right)-\log \left(D_{\mathrm{p}, 1}\right)}$.

In the equation, $\mathrm{d} C$ is the mass concentration of trace elements in a size bin, and $\operatorname{d} \log \left(D_{\mathrm{p}}\right)$ is the difference in the $\log$ of the bin width. The $d \log \left(D_{\mathrm{p}}\right)$ is calculated by subtracting the $\log$ of the lower bin boundary $\left(\log \left(D_{\mathrm{p}, \mathrm{u}}\right)\right)$ from the $\log$ of the upper bin boundary $\left(\log \left(D_{\mathrm{p}, 1}\right)\right)$. The $k$-means clustering algorithm was used to cluster the average particle-size distribution of each trace element. The optimal number of clusters ( $k$ ) was selected by choosing the $k$ with the highest CalińskiHarabasz index (Caliński and Harabasz, 1974).

\subsubsection{Atmospheric dry deposition flux estimation}

Dry deposition flux $\left(F_{\mathrm{d}}, \mathrm{mg} \mathrm{m}^{-2} \mathrm{yr}^{-1}\right)$ of each element in aerosols was calculated from the concentration $\left(C_{\mathrm{e}}, \mathrm{ng} \mathrm{m}^{-3}\right)$ of the trace element in the air and dry deposition velocity $\left(V_{\mathrm{d}}\right.$, $\left.\mathrm{cm} \mathrm{s}^{-1}\right)$ :

$F_{\mathrm{d}}=0.315 \times V_{\mathrm{d}} \times C_{\mathrm{e}}$, 
where 0.315 is a unit conversion factor (Gao et al., 2013). The $V_{\mathrm{d}}$ for each trace element was computed by dry deposition rates $\left(V_{\mathrm{d} i}, \mathrm{~cm} \mathrm{~s}^{-1}\right)$ and particle distribution ratios $\left(P_{\mathrm{dr} i}\right.$, $\%$ ) following the equation

$$
\sum_{i=1}^{10} V_{\mathrm{d} i} \times P_{\mathrm{dr} i}
$$

The $P_{\mathrm{dr} i}$ was derived from the concentrations of trace elements in different size fractions $i$, and $V_{\mathrm{d} i}$ was estimated using a combination model of Williams (1982) and Quinn and Ondov (1998). This model includes the effects of wind speed, air-water temperature difference, sea surface roughness, spray formation at high wind speed, and relative humidity. Meteorological parameters used for estimating dry deposition rates were measured in situ by the weather station with $1 \mathrm{~min}$ temporal resolution that was converted to $1 \mathrm{~h}$ averages. Sea surface temperature data were obtained from the Palmer Station Long-Term Ecological Research (LTER) study (https://oceaninformatics.ucsd. edu/datazoo/catalogs/pallter/datasets/28, last access: 29 January 2021). Dry deposition rates of coarse-mode particles were dominated by gravitational settling, whereas the dry deposition rates of smaller particles were controlled by environmental factors, including wind speed, relative humidity, air temperature, and sea surface temperature (Fig. 2). Therefore, the uncertainties of the dry deposition velocity estimation for the elements that were dominated by coarse particles were about $\pm 30-60 \%$, and the uncertainty of the fine-particledominated element $(\mathrm{Pb})$ was about $\pm 100 \%$. The overall estimation of dry deposition flux usually carries substantial uncertainty (a factor of 2 to 4 ) due to the limited sampling volume and the assumptions inherent to the $V_{\mathrm{d} i}$ estimation (Duce et al., 1991; Gao et al., 2020). The dry deposition velocities determined for each element are reported in Table 3. Dry deposition fluxes were calculated for the trace elements showing clear particle-size distribution patterns: $\mathrm{Al}, \mathrm{P}, \mathrm{Ca}$, $\mathrm{Ti}, \mathrm{V}, \mathrm{Mn}, \mathrm{Ce}$, and $\mathrm{Pb}$. For $\mathrm{Ni}, \mathrm{Cu}$, and $\mathrm{Zn}$, which did not show clear size distributions, the ranges of their dry deposition fluxes were also estimated by applying their mean concentrations to the lowest $\left(\mathrm{Pb}, 0.11 \pm 0.12 \mathrm{~cm} \mathrm{~s}^{-1}\right)$ and highest (Al, $0.49 \pm 0.28 \mathrm{~cm} \mathrm{~s}^{-1}$ ) dry deposition velocities. The dry deposition fluxes of dust were estimated based on the concentrations and particle-size distributions of $\mathrm{Al}$ in aerosols, assuming that $\mathrm{Al}$ accounted for $8 \%$ of dust mass (Taylor and McLennan, 1995).

\subsubsection{Air mass back trajectories}

To explore possible source regions of air masses affecting trace elements in aerosols collected at Palmer Station, the NOAA Hybrid Single-Particle Lagrangian Integrated Trajectory Model (HYSPLIT) was used to calculate $72 \mathrm{~h}$ air mass back trajectories for each sampling duration (Rolph et al., 2017). In this study, the HYSPLIT model was driven by the

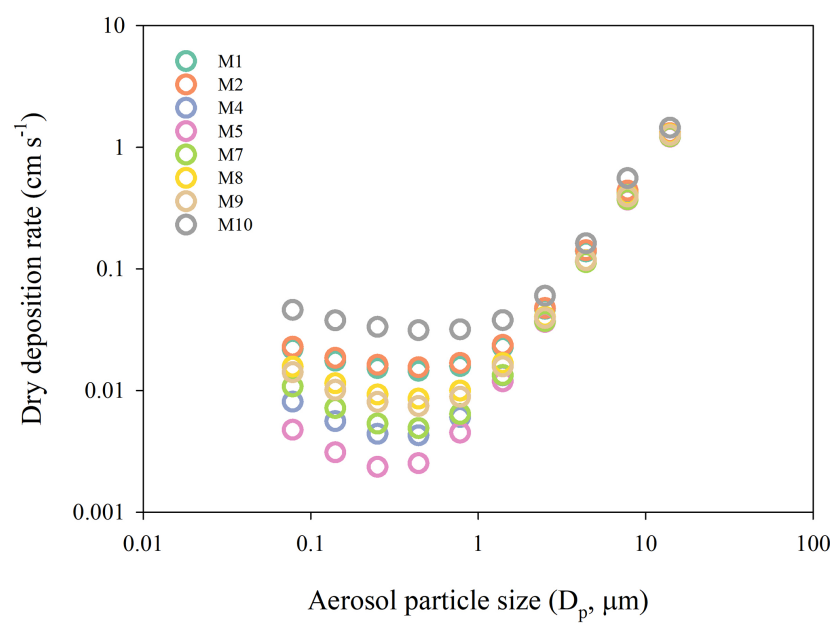

Figure 2. Median dry deposition rates of each size class of aerosol particles for samples M1-M10, collected between November 2016 and January 2017. The dry deposition rate is not only a function of aerosol particle size $\left(D_{\mathrm{p}}\right)$ but also depends on meteorological conditions (see text).

meteorological data from the Global Data Assimilation System (GDAS) with a $0.5^{\circ}$ resolution. Each air mass back trajectory was calculated at $3 \mathrm{~h}$ intervals and started from onehalf mixed boundary layer height. The back trajectories during each sampling period were used to calculate trajectory frequencies, which were defined by the following equation:

trajectory frequencies

$=100 \times \frac{\text { number of endpoints per grid square }}{\text { number of trajectories }}$.

\section{Results and discussion}

\subsection{Enrichment factors of trace elements}

Crustal enrichment factors of trace elements in aerosols were calculated as the first step of source identification (Fig. 3). Two major EF groups were found, representing crustal and non-crustal elements as follows.

\subsubsection{Crustal elements (P, Ti, V, Mn, Ce)}

The values of $\mathrm{EF}_{\text {crust }}$ for $\mathrm{Ti}, \mathrm{V}, \mathrm{Mn}$, and $\mathrm{Ce}$ in aerosol samples were less than 10 , indicating that a crustal source is the dominant source for those elements (Fig. 3). As typical lithogenic elements (Boës et al., 2011), Ti and Mn in aerosols over oceanic regions are usually derived from natural dust emissions (Shelley et al., 2015; Marsay et al., 2018; Buck et al., 2019). Likewise, V and Ce in aerosols over the South Pole were reportedly dominated by crustal weathering (Zoller et al., 1974). In addition to crustal emissions, long-range transport may deliver some portion of these trace elements from remote sources to Antarctica (Wagener et al., 2008). For ex- 


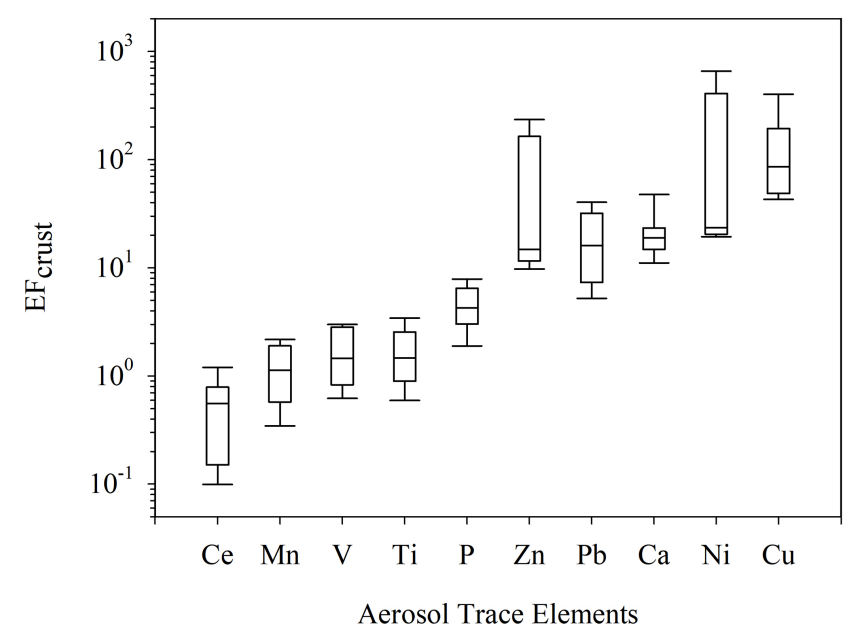

Figure 3. Box plots of $\mathrm{EF}_{\text {crust }}$ for trace elements in aerosols collected at Palmer Station between November 2016 and January 2017. The central horizontal line is the mean value, and the bottom and the top of each box are the 25th and 75th percentiles. The upper and lower horizontal bars indicate the 5th and 95th percentiles of the data.

ample, aerosol Ce and Mn derived from anthropogenic emissions were thought to be contributed by additives in vehicle fuels (Fomba et al., 2013; Gantt et al., 2014), and V in aerosols was found associated with ship emissions due to the use of heavy-oil fuel (Keywood et al., 2020). However, the $\mathrm{EF}_{\text {crust }}$ results from this study suggest that nearby fuel combustion did not cause significant enrichment of $\mathrm{V}$ in aerosols at Palmer Station. Similarly, unenriched V was observed at McMurdo Station, where lightweight-fuel oil was used that was not a significant source of V (Lowenthal et al., 2000). We conclude that Ti, Mn, V, and Ce observed at Palmer Station were derived primarily from crustal sources.

The range of $\mathrm{EF}_{\text {crust }}$ for $\mathrm{P}$ was between 2 and 8, relatively higher than that of the other crustal elements. In Antarctic soils, P has been widely studied (Campbell and Claridge, 1987; Blecker et al., 2006; Prietzel et al., 2019). Around the Antarctic coast, including the northern end of the Antarctic Peninsula, high $\mathrm{P}$ inputs to the surface soil were found in seabird colonies (Otero et al., 2018), and a high enrichment of $\mathrm{P}\left(\mathrm{EF}_{\text {crust }}=33\right)$ was reported previously at King George Island (Artaxo et al., 1990). The closest potential source, the penguin colony on Torgersen Island, is only about $1 \mathrm{~km}$ from Palmer Station. Given that regional wind-induced dust likely affects aerosol composition over the Antarctic Peninsula (Asmi et al., 2018; Gao et al., 2020), soil-derived P is likely to be emitted to the atmosphere. In addition, biogenic activities in Antarctica also produce abundant gaseous P, such as phosphine, through anaerobic microbial processes in soils and animal digestives, and phosphine gas can be transformed to other low-volatility P-containing compounds in the atmosphere or soils (Zhu et al., 2006). Primary biogenic aerosols, sea-salt aerosols, and volcanic emissions could also contribute $\mathrm{P}$ to the atmosphere, causing an elevated $\mathrm{EF}_{\text {crust }}$ for P (Zhao et al., 2015; Trabelsi et al., 2016).

\subsubsection{Non-crustal elements $(\mathrm{Ca}, \mathrm{Ni}, \mathrm{Cu}, \mathrm{Zn}, \mathrm{Pb})$}

The enrichment factors of atmospheric $\mathrm{Ni}, \mathrm{Cu}, \mathrm{Zn}$, and $\mathrm{Pb}$ relative to the crustal element $\mathrm{Al}$ were found to be greater than 10 in some samples, suggesting contributions from noncrustal sources during the corresponding sampling periods in this study (Fig. 3). High enrichments of these elements in Antarctica have commonly been associated with long-range transport derived from anthropogenic emission (Boutron and Lorius, 1979; Maenhaut et al., 1979; Dick, 1991; Artaxo et al., 1992; McConnell et al., 2014; Xu and Gao, 2014). Aerosol $\mathrm{Cu}, \mathrm{Zn}$, and $\mathrm{Pb}$ are contributed primarily by combustion or industrial activities (Pacyna and Pacyna, 2001). Strong variations of the $\mathrm{EF}_{\text {crust }}$ of $\mathrm{Cu}, \mathrm{Zn}$, and $\mathrm{Pb}$ observed in snow samples at Dome $\mathrm{C}$, Antarctica, over the 20th century were attributed to volcanic activities (Boutron and Lorius, 1979). On the other hand, heavy-oil combustion was found to be a major source of aerosol $\mathrm{Ni}$ and $\mathrm{V}$, and $\mathrm{V} / \mathrm{Ni}$ ratios are usually used to identify shipping emissions (Keywood et al., 2020). Nevertheless, the $\mathrm{V} / \mathrm{Ni}$ measured at Palmer Station ranged from 0.01 to 0.2 , much lower than the $\mathrm{V} / \mathrm{Ni}=$ $3.2 \pm 0.8$ characteristic of the discharge from ship engines (Viana et al., 2009, 2014; Celo et al., 2015). Hence, despite the recent increase in tourist ship traffic (Lynch et al., 2010), it seems that Palmer Station was barely impacted by ship emissions, which is consistent with the $\mathrm{EF}_{\text {crust }}$ of V. As a common crustal element, $\mathrm{Ca}$ accounts for about $3.5 \%$ of the weight of Earth's crust (Taylor and McLennan, 1995), while $\mathrm{Ca}$ is also a conservative major ion in seawater (Millero, 2016). The high $\mathrm{EF}_{\text {crust }}$ for $\mathrm{Ca}$ at Palmer Station suggests that aerosol $\mathrm{Ca}$ was mainly derived from sea salt.

\subsection{Concentrations of trace elements}

The concentrations of $\mathrm{Ca}$ and $\mathrm{Al}$, the two major elements measured in this study, were 1 to several orders of magnitude higher than other elements (Table 1). To place all of the results of this study into the context of past investigations, we provide a visual comparison of measured concentrations of aerosol trace elements over Antarctica (Fig. 4).

\subsubsection{Mineral dust (Al, P, Ti, V, Mn, Ce)}

The concentrations of $\mathrm{Al}$ in aerosols varied from 1.2 to $7.9 \mathrm{ng} \mathrm{m}^{-3}$ with an average of $4.3 \mathrm{ng} \mathrm{m}^{-3}$ during the 20162017 austral summer in this study. These concentrations are lower than the 4-year mean $\mathrm{Al}$ values of $\sim 13 \mathrm{ng} \mathrm{m}^{-3}$ at King George Island $\left(62^{\circ} \mathrm{S}, 58^{\circ} \mathrm{W}\right)$, at the northern end of the Antarctic Peninsula (Artaxo et al., 1992), but were slightly higher than the 2-year mean $\mathrm{Al}$ concentrations of $1.9 \mathrm{ng} \mathrm{m}^{-3}$ observed at King Sejong Station $\left(62^{\circ} \mathrm{S}, 59^{\circ} \mathrm{W}\right)$ (Mishra et al., 2004), the summer mean of $0.194 \mathrm{ng} \mathrm{m}^{-3}$ at the Larsen Ice Shelf to the southeast of Palmer Station (Dick 

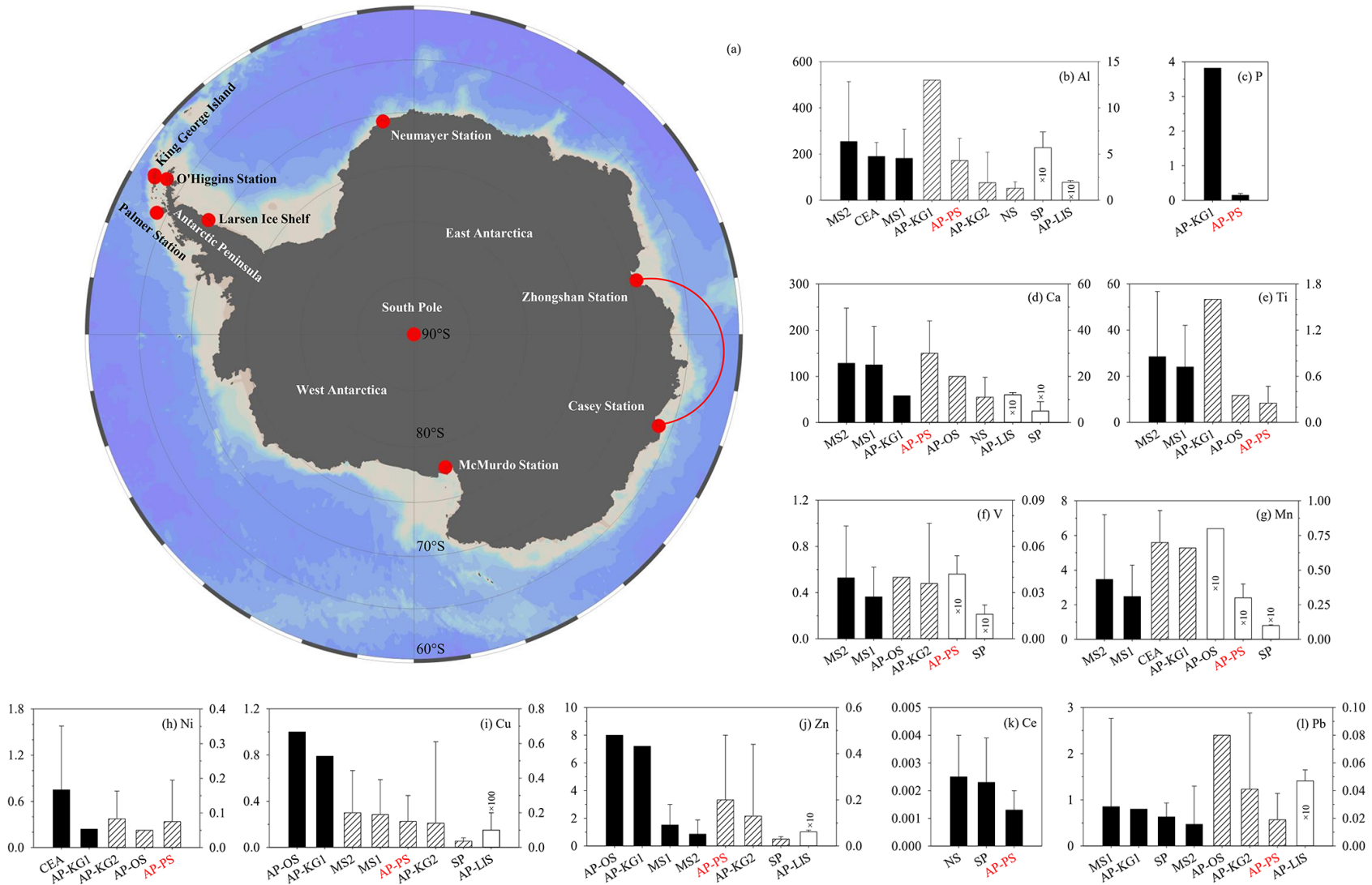

Figure 4. Comparison of the concentrations of aerosol trace elements $\left(\mathrm{ng} \mathrm{m}^{-3}\right)$ over Antarctica at coastal land-based sites. The cruise from Zhongshan Station to Casey Station was used to represent coastal East Antarctica. All concentrations are sorted in descending order from left to right. The left $y$ axis shows concentrations for the black bars, whereas the right $y$ axis corresponds to the striped and white bars. Some extremely low values are multiplied by 10 or 100 for display purposes, as marked above the corresponding white bars. Error bars show the standard derivation of the trace element concentrations in each study if available. Data are from observations conducted at the South Pole (SP) (Zoller et al., 1974); Hut Point site (MS1, PM10) and Radar Sat Dome site (MS2, PM 10 ) at McMurdo Station (Mazzera et al., 2001); on a cruise between Zhongshan Station and Casey Station in coastal East Antarctica (CEA) (Xu and Gao, 2014); at Neumayer Station (NS) (Weller et al., 2008); and at five sites on the Antarctic Peninsula (AP), including Comandante Ferraz Antarctic Station (KG1) (Artaxo et al., 1990, 1992) and King Sejong Station (KG2) (Mishra et al., 2004) at King George Island, Bernardo O'Higgins Station (OS, PM2.5) (Préndez et al., 2009), Larsen Ice Shelf (LIS) (Dick, 1991), and Palmer Station (PS, this study, marked by red arrow) at Anvers Island. Artaxo et al. (1990, 1992), Mazzera et al. (2001), and Préndez et al. (2009) used X-ray fluorescence to measure the total concentrations of trace elements. All the other studies applied acid digestion methods. Our study at Palmer Station is marked in red.

et al., 1991), the 5-year summer mean of $1.3 \mathrm{ng} \mathrm{m}^{-3}$ in East Antarctica (Weller et al., 2008), and the summer average of $0.57 \mathrm{ng} \mathrm{m}^{-3}$ measured at the South Pole (Zoller et al., 1974; Maenhaut et al., 1979) (Fig. 4b). All these results, including ours, were much lower than the average $\mathrm{Al}$ concentrations of 180 and $250 \mathrm{ng} \mathrm{m}^{-3}$ observed at the two sites at McMurdo Station (Mazzera et al., 2001) due to the impact of the McMurdo Dry Valleys (Fig. 4b). The nearby McMurdo Sound was reported as the dustiest site in Antarctica (Winton et al., 2016). These aerosol Al concentrations are also lower than the average $\mathrm{Al}$ concentration of $190 \mathrm{ng} \mathrm{m}^{-3}$ observed in coastal East Antarctica, where the samples were also impacted by air masses passing over McMurdo regions (Xu and Gao, 2014) (Fig. 4b). The concentrations of Ti ranged from 140 to $800 \mathrm{pg} \mathrm{m}^{-3}$ with an average of $250 \mathrm{pg} \mathrm{m}^{-3}$, while the concentration of $\mathrm{Mn}$ ranged from 17 to $44 \mathrm{pg} \mathrm{m}^{-3}$ with an average of $30 \mathrm{pg} \mathrm{m}^{-3}$. Both Ti and Mn concentrations at Palmer Station were lower than yearly mean concentrations at King George Island (average Ti: $1600 \mathrm{pg} \mathrm{m}^{-3}$; average $\mathrm{Mn}: 660 \mathrm{pg} \mathrm{m}^{-3}$ ) (Artaxo et al., 1992), and they were also lower than the summer mean $\mathrm{PM}_{10}$ concentrations at McMurdo Station (Ti: $26000 \mathrm{pg} \mathrm{m}^{-3}$; Mn: $3000 \mathrm{pg} \mathrm{m}^{-3}$ ) (Mazzera et al., 2001). However, these Ti and Mn values observed at Palmer Station were of the same magnitude with the $\mathrm{PM}_{2.5}$ concentrations during the austral summer near the Chilean base Bernardo O'Higgins, located on the northwest coast of the Antarctic Peninsula (Préndez et al., 2009), and with the concentrations in bulk aerosols over coastal East 
Antarctica in austral summer (Mn: $450-1200 \mathrm{pg} \mathrm{m}^{-3}$ with an average of $700 \mathrm{pg} \mathrm{m}^{-3}$ ) (Xu and Gao, 2014) (Fig. 4e and $\mathrm{g})$. The concentrations of $\mathrm{V}$ ranged from 2.7 to $6.1 \mathrm{pg} \mathrm{m}^{-3}$ with a mean value of $4.2 \mathrm{pg} \mathrm{m}^{-3}$, which is higher than the numbers reported at the South Pole (average $\sim 1.5 \mathrm{pg} \mathrm{m}^{-3}$ ) (Zoller et al., 1974; Maenhaut et al., 1979) (Fig. 4f). However, the $\mathrm{V}$ concentration observed at Palmer Station was much lower than previous observations in the North Atlantic Ocean (50-3170 $\mathrm{pg} \mathrm{m}^{-3}$ ) (Fomba et al., 2013) and eastern Pacific Ocean (average $150 \mathrm{pg} \mathrm{m}^{-3}$ ) (Buck et al., 2019). On the other hand, Ce demonstrated an average concentration of $1.3 \pm 0.69 \mathrm{pg} \mathrm{m}^{-3}$, which is consistent with the Ce concentrations reported at Neumayer Station, Antarctica (Weller et al., 2008) (Fig. 4k). The low concentrations of aerosol V and Ce suggest that Palmer Station was not significantly influenced by fossil fuel combustion. The $\mathrm{P}$ concentrations in aerosols during this study ranged from 85 to $250 \mathrm{pg} \mathrm{m}^{-3}$ with an average of $150 \mathrm{ng} \mathrm{m}^{-3}$. The concentrations of aerosol $\mathrm{P}$ at Palmer Station were lower than that at King George Island $\left(3820 \mathrm{pg} \mathrm{m}^{-3}\right.$ ) (Artaxo et al., 1990). Comparing global aerosol $\mathrm{P}$ concentrations, we find that $\mathrm{P}$ concentrations over the Antarctic Peninsula are in the same range as those over the central Pacific Ocean (Chen, 2004). In this study, nss$\mathrm{K}^{+}$was used as a tracer of biomass burning (Winton et al., 2015). The calculated nss- $\mathrm{K}^{+}$was indistinguishable from 0 , suggesting that $\mathrm{K}^{+}$in aerosol at Palmer Station was primarily derived from seawater, not from biomass burning through long-range transport. These results agree well with the air mass back trajectories, which indicate that most samples collected during this study were barely affected by South America (Fig. 5). In addition, for most of the $72 \mathrm{~h}$ air mass back trajectories, the highest frequencies were found around the northern Antarctic Peninsula, suggesting that aerosol crustal elements observed at Palmer Station were impacted by sources in that region (Fig. 5).

\subsubsection{Anthropogenic aerosols $(\mathrm{Ni}, \mathrm{Cu}, \mathrm{Zn}, \mathrm{Pb})$}

The concentrations of $\mathrm{Ni}, \mathrm{Cu}, \mathrm{Zn}$, and $\mathrm{Pb}$ were more variable than the crustal elements. High levels of these elements would suggest an effect of a polluted air mass derived from long-transport or regional air pollution (Artaxo et al., 1992). The highest concentration of Ni observed during this study was $320 \mathrm{pg} \mathrm{m}^{-3}$, with an average of $75 \mathrm{pg} \mathrm{m}^{-3}$, while the lowest $\mathrm{Ni}$ concentration was below LOD $\left(<20 \mathrm{pg} \mathrm{m}^{-3}\right)$. Samples M2 and M10 showed relatively high values of $\mathrm{Ni}$ of 320 and $200 \mathrm{pg} \mathrm{m}^{-3}$, respectively, while the concentrations of $\mathrm{Ni}$ in M1, M5, and M6 were much lower, ranging from 17 to $37 \mathrm{pg} \mathrm{m}^{-3}$. The concentrations of $\mathrm{Cu}$ varied from $<20-480 \mathrm{pg} \mathrm{m}^{-3}$ (average $150 \mathrm{pg} \mathrm{m}^{-3}$ ), while $\mathrm{Zn}$ ranged from $<30-710 \mathrm{pg} \mathrm{m}^{-3}$ (average $200 \mathrm{pg} \mathrm{m}^{-3}$ ). These results indicate that the concentrations of these elements in aerosols varied dramatically throughout the study period, likely affected by the source strength and meteorological conditions. From the air mass back trajectories, the samples with high
Ni (M2, M10), Cu (M1, M2, M4, M10), and Zn (M5) all were impacted by a significant amount of air masses from the South Pacific Ocean and South America (Fig. 5). The back trajectories of air masses of M7 did not touch South America, but the concentration of $\mathrm{Zn}$ in this sample was high. Given the fact that aerosol $\mathrm{Zn}$ was found in both fineand coarse-mode fractions (Table 2), both local sources and long-range transport may contribute to this element in the air. Artaxo et al. (1992) collected aerosol samples using a two-stage size-segregated sampler and observed high concentrations of $\mathrm{Ni}, \mathrm{Cu}$, and $\mathrm{Zn}$ - with averages of 240, 790, and $7200 \mathrm{pg} \mathrm{m}^{-3}$, respectively - at King George Island in summertime (Fig. 4h, i and j), much higher than the results from this study. The high concentrations may have resulted from local polluted dust emissions around their sampling site (Hong et al., 1999). In addition, their sampling site was considerably north of Palmer Station and may be more likely to be impacted by air masses from South America (Chambers et al., 2014). In South America, high enrichment of $\mathrm{Ni}, \mathrm{Cu}, \mathrm{Zn}$, and $\mathrm{Pb}$ in fine-mode particles was reported to be primarily associated with vehicle emission, soil dust, and oil combustion (Artaxo et al., 1999; Jasan et al., 2009). Moreover, miming activities were suggested as an important source, especially at remote sites in South America (Carrasco and Préndez, 1991; Klumpp et al., 2000). On the other hand, the concentrations of $\mathrm{Ni}, \mathrm{Cu}$, and $\mathrm{Zn}$ at Palmer Station were lower than at some other sites in Antarctica. At McMurdo Station, the average concentrations of $\mathrm{Cu}$ and $\mathrm{Zn}$ in $\mathrm{PM}_{10}$ samples were 200 and $1200 \mathrm{pg} \mathrm{m}^{-3}$ (Mazzera et al., 2001) (Fig. 4i and j). Over coastal East Antarctica, the Ni concentrations in aerosols ranged from $<3$ to $2200 \mathrm{pg} \mathrm{m}^{-3}$ with an average of $750 \mathrm{pg} \mathrm{m}^{-3}$ (Xu and Gao, 2014) (Fig. 4h).

The concentrations of aerosol $\mathrm{Pb}$ observed at Palmer Station ranged from 5.0 to $60 \mathrm{pg} \mathrm{m}^{-3}$ with an average of $19 \mathrm{pg} \mathrm{m}^{-3}$, higher than the average concentration of $4.7 \mathrm{pg} \mathrm{m}^{-3}$ previously observed on the east coast of the Antarctic Peninsula in austral summer (Dick, 1991) (Fig. 4l) and the annual average concentration of $11 \mathrm{pg} \mathrm{m}^{-3}$ in Tasmania (Bollhöfer et al., 2005). However, the average $\mathrm{Pb}$ concentration reported at King George Island was about $800 \mathrm{pg} \mathrm{m}^{-3}$ (Artaxo et al., 1992), considerably higher than observed in this study (Fig. 41). The two highest $\mathrm{Pb}$ concentrations observed during this study were in M4 $\left(60 \mathrm{pg} \mathrm{m}^{-3}\right)$ and M5 $\left(30 \mathrm{pg} \mathrm{m}^{-3}\right)$. The results of air mass back trajectories for M4 and M5 show that the air masses were derived in part from South America, which suggests additional contribution from long-range transport (Fig. $5 \mathrm{~b}$ and c). However, when the $72 \mathrm{~h}$ air mass back trajectories did not intersect the South American continent, the concentrations of $\mathrm{Pb}$ in those samples were significantly lower (Fig. 5a and d). The low concentrations of $\mathrm{Pb}$ observed in samples associated with air masses that did not pass over southern South America suggest that local anthropogenic emissions were negligible. Thus the major source of non-crustal elements in aerosols over the study region may be long-range transport of aerosols from southern 

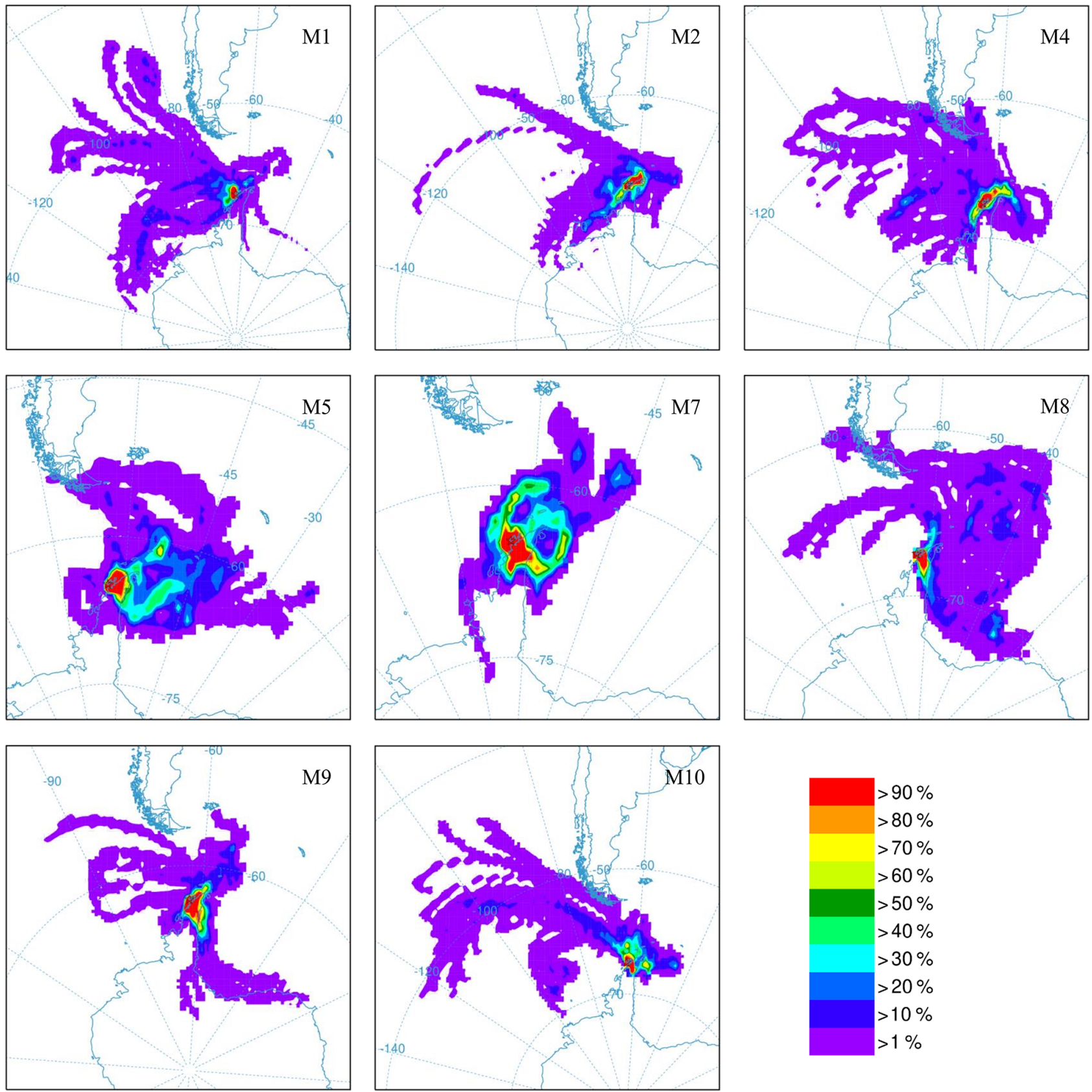

Figure 5. Frequencies of $72 \mathrm{~h}$ air mass back trajectories for samples collected at Palmer Station: M1 (19-26 November 2016), M2 (26 November-4 December 2016), M4 (9-17 December 2016), M5 (17-24 December 2016), M7 (1-8 January 2017), M8 (8-15 January 2017), M9 (15-23 January 2017), and M10 (23-30 January 2017).

hemispheric continental regions containing a mixture of anthropogenic and crustal emissions.

\subsubsection{Sea-salt aerosol $\left(\mathrm{Ca}, \mathrm{Na}^{+}, \mathrm{K}^{+}\right)$}

The concentrations of sea-salt species were much higher than the other trace elements (Table 1). The concentrations of aerosol $\mathrm{Ca}$ were the highest among all elements measured in this study (range of $16-53 \mathrm{ng} \mathrm{m}^{-3}$ and mean value of
$30 \mathrm{ng} \mathrm{m}^{-3}$ ). The mean value of $\mathrm{Ca}$ is close to the mean $\mathrm{Ca}$ concentrations observed previously in coastal regions of the Antarctic Peninsula (Artaxo et al., 1992; Weller et al., 2008) (Fig. 4d). In addition, $\mathrm{Na}^{+}$, as a tracer of sea salt, and $\mathrm{K}^{+}$, as a tracer of biomass burning (Zhu et al., 2015), were used to further evaluate the contribution of trace elements from other sources. The concentrations of $\mathrm{Na}^{+}$and $\mathrm{K}^{+}$showed average concentrations of $890 \pm 310$ and $28 \pm 11 \mathrm{ng} \mathrm{m}^{-3}$, respectively. 
Table 2. Concentrations of trace elements and ions in aerosols over Palmer Station, western Antarctic Peninsula.

\begin{tabular}{|c|c|c|c|c|c|c|c|c|c|c|c|c|}
\hline Element/ion & Units & Size fraction & M1 & M2 & M4 & M5 & M7 & M8 & M9 & M10 & Mean & SD \\
\hline \multirow{3}{*}{$\mathrm{Al}$} & \multirow{3}{*}{$n g m^{-3}$} & Coarse & 6.9 & 7.9 & 4.4 & 3.3 & 3.7 & 2.2 & 2.5 & 0.83 & 4.0 & 2.4 \\
\hline & & Fine & ND & ND & 1.6 & 0.13 & 0.30 & 0.11 & 0.17 & 0.41 & 0.34 & 0.53 \\
\hline & & Sum & 6.9 & 7.9 & 6.0 & 3.4 & 4.0 & 2.3 & 2.7 & 1.2 & 4.3 & 2.4 \\
\hline \multirow{3}{*}{$\mathrm{P}$} & \multirow{3}{*}{$\operatorname{pg~m}^{-3}$} & Coarse & 110 & 250 & 150 & 180 & 130 & 95 & 140 & 85 & 140 & 53 \\
\hline & & Fine & ND & ND & ND & ND & ND & ND & 15 & ND & 1.9 & 5.3 \\
\hline & & Sum & 110 & 250 & 150 & 180 & 130 & 95 & 160 & 85 & 150 & 54 \\
\hline \multirow{3}{*}{$\mathrm{Ca}$} & \multirow{3}{*}{$n g m^{-3}$} & Coarse & 42 & 47 & 25 & 24 & 14 & 18 & 15 & 20 & 26 & 12 \\
\hline & & Fine & 8.9 & 5.4 & 5.4 & 3.2 & 2.4 & 3.1 & 3.9 & 2.0 & 4.3 & 2.2 \\
\hline & & Sum & 50 & 53 & 31 & 27 & 16 & 21 & 19 & 22 & 30 & 14 \\
\hline \multirow{3}{*}{$\mathrm{Ti}$} & \multirow{3}{*}{$\mathrm{pg} \mathrm{m}^{-3}$} & Coarse & 150 & 800 & 120 & 150 & 170 & 130 & 190 & 94 & 230 & 230 \\
\hline & & Fine & ND & ND & 48 & 20 & 24 & 9.0 & 16 & 65 & 23 & 23 \\
\hline & & Sum & 150 & 800 & 170 & 170 & 190 & 140 & 210 & 160 & 250 & 220 \\
\hline \multirow{3}{*}{$\mathrm{V}$} & \multirow{3}{*}{$\mathrm{pg} \mathrm{m}^{-3}$} & Coarse & 3.2 & 3.6 & 2.4 & 3.1 & 4.8 & 4.1 & 5.3 & 2.4 & 3.6 & 1.1 \\
\hline & & Fine & ND & 1.4 & 1.2 & ND & 0.27 & 0.53 & 0.77 & 0.28 & 0.57 & 0.55 \\
\hline & & Sum & 3.2 & 5.0 & 3.7 & 3.1 & 5.0 & 4.6 & 6.1 & 2.7 & 4.2 & 1.2 \\
\hline \multirow{3}{*}{$\mathrm{Mn}$} & \multirow{3}{*}{$\mathrm{pg} \mathrm{m}^{-3}$} & Coarse & 17 & 42 & 15 & 27 & 32 & 34 & 35 & 14 & 27 & 10 \\
\hline & & Fine & 1.2 & 2.3 & 8.2 & 0.90 & 2.9 & 3.6 & 3.9 & 2.8 & 3.2 & 2.3 \\
\hline & & Sum & 18 & 44 & 23 & 27 & 35 & 38 & 39 & 17 & 30 & 10 \\
\hline \multirow{3}{*}{$\mathrm{Ni}$} & \multirow{3}{*}{$\mathrm{pg} \mathrm{m}^{-3}$} & Coarse & ND & 320 & ND & 17 & 23 & ND & ND & ND & 45 & 110 \\
\hline & & Fine & 37 & ND & ND & ND & ND & ND & $\mathrm{ND}$ & 200 & 30 & 70 \\
\hline & & Sum & 37 & 320 & ND & 17 & 23 & ND & ND & 200 & 75 & 120 \\
\hline \multirow{3}{*}{$\mathrm{Cu}$} & \multirow{3}{*}{$\mathrm{pg} \mathrm{m}^{-3}$} & Coarse & 170 & 200 & 17 & ND & ND & ND & $\mathrm{ND}$ & 120 & 63 & 86 \\
\hline & & Fine & 69 & 280 & 92 & 52 & 110 & ND & 36 & 34 & 84 & 86 \\
\hline & & Sum & 240 & 480 & 110 & 52 & 110 & ND & 36 & 150 & 150 & 150 \\
\hline \multirow{3}{*}{$\mathrm{Zn}$} & \multirow{3}{*}{$\mathrm{pg} \mathrm{m}^{-3}$} & Coarse & 40 & 68 & 32 & 590 & 280 & 25 & ND & 46 & 140 & 200 \\
\hline & & Fine & 51 & ND & 30 & 120 & 300 & ND & ND & 56 & 70 & 100 \\
\hline & & Sum & 90 & 68 & 61 & 710 & 580 & 25 & ND & 100 & 200 & 280 \\
\hline \multirow{3}{*}{$\mathrm{Ce}$} & \multirow{3}{*}{$\mathrm{pg} \mathrm{m}^{-3}$} & Coarse & 0.73 & 0.57 & 0.62 & 1.8 & 1.6 & 2.1 & 1.5 & 0.41 & 1.2 & 0.65 \\
\hline & & Fine & 0.084 & 0.051 & 0.12 & 0.13 & 0.12 & 0.19 & 0.26 & 0.14 & 0.14 & 0.064 \\
\hline & & Sum & 0.81 & 0.62 & 0.74 & 2.0 & 1.7 & 2.2 & 1.8 & 0.55 & 1.3 & 0.69 \\
\hline \multirow{3}{*}{$\mathrm{Pb}$} & \multirow{3}{*}{$\mathrm{pg} \mathrm{m}^{-3}$} & Coarse & 5.1 & 2.4 & 13.8 & 2.2 & 2.4 & 2.7 & 0.70 & 5.0 & 4.3 & 4.1 \\
\hline & & Fine & 3.8 & 12 & 46 & 28 & 17 & 4.5 & 4.3 & 1.7 & 15 & 16 \\
\hline & & Sum & 9.0 & 14 & 60 & 30 & 19 & 7.2 & 5.0 & 6.6 & 19 & 19 \\
\hline \multirow{3}{*}{$\mathrm{Na}^{+}$} & & Coarse & 1100 & 1000 & 900 & 870 & 430 & 450 & 520 & 730 & 749 & 260 \\
\hline & $\mathrm{ng} \mathrm{m}^{-3}$ & Fine & 220 & 210 & 160 & 120 & 75 & 99 & 89 & 90 & 130 & 57 \\
\hline & & Sum & 1300 & 1200 & 1100 & 1000 & 510 & 550 & 610 & 820 & 890 & 310 \\
\hline & & Coarse & 34 & 39 & 34 & 31 & 14 & 12 & 17 & 24 & 26 & 10 \\
\hline $\mathrm{K}^{+}$ & $n g m^{-3}$ & Fine & 4.9 & 4.5 & 2.5 & 3.2 & 1.6 & 1.8 & 1.5 & 1.4 & 2.3 & 1.1 \\
\hline & & Sum & 39 & 43 & 37 & 34 & 15 & 14 & 19 & 25 & 28 & 11 \\
\hline
\end{tabular}

Thus, the $\mathrm{Na}^{+} / \mathrm{K}^{+}(32 \pm 3.5)$ ratios were close to the average $\mathrm{Na} / \mathrm{K}$ mass ratio in seawater (27) and the $\mathrm{Na}^{+} / \mathrm{Ca}$ ratios $(31 \pm 5.5)$ were close to the average $\mathrm{Na}^{+} / \mathrm{Ca}$ ratio in seawater (26) as well (Millero, 2016). Such results agree well with the $\mathrm{Na} / \mathrm{K}(29.7)$ and $\mathrm{Na} / \mathrm{Ca}$ (39.9) ratios measured in snow samples collected at James Ross Island (Aristarain et al., 1982).
Therefore, the $\mathrm{Ca}$ and $\mathrm{K}^{+}$in aerosols were derived primarily from sea salt at Palmer Station.

\subsection{Aerosol particle-size distributions of trace elements}

The concentrations of trace elements in aerosols observed during this study varied as a function of particle size. We 


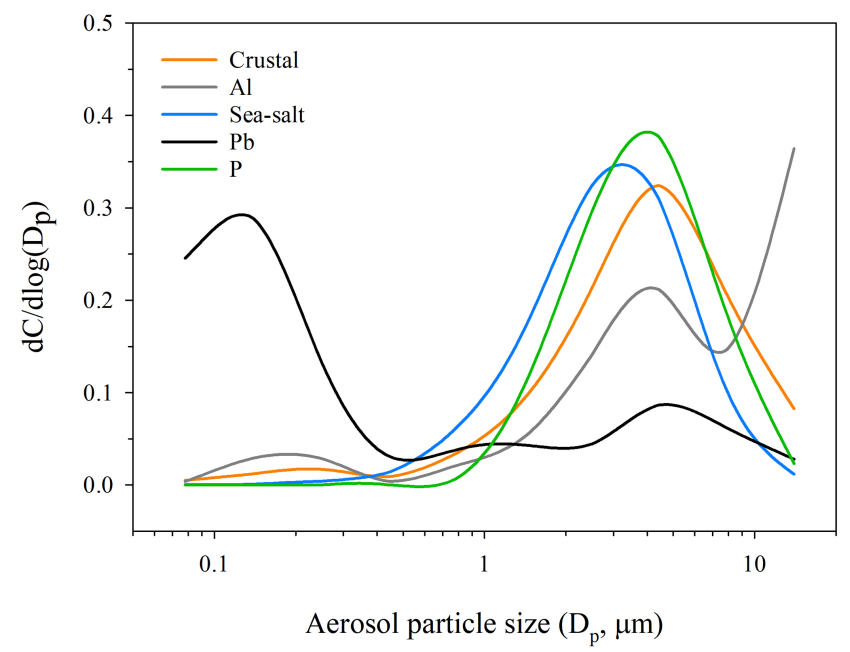

Figure 6. The results of $k$-means clustering on the normalized mean aerosol particle-size distributions. The crustal cluster includes Ti, V, $\mathrm{Mn}$, and Ce; the sea-salt cluster includes $\mathrm{Na}^{+}, \mathrm{K}^{+}$, and $\mathrm{Ca}$.

applied $k$-means clustering to the full data set, and the results indicate that aerosol trace elements in the austral summer at Palmer Station can be classified into five groups based on their normalized particle-size distributions (Fig. 6), with each group showing a unique size distribution pattern: (1) crustal elements from crustal weathering and wind-induced resuspension of soil particles, (2) Al dominated by local minerals, (3) $\mathrm{Pb}$ from anthropogenic sources as a result of long-range transport, (4) sea-salt elements from the ocean through bursting bubbles of seawater, and (5) P from local biogenic and soil resuspension. The particle-size distribution of each element can be classified as single mode, bimodal, or trimodal, which hints that the elements derived from distinct sources or experienced different processes during the transport to the sampling site.

\subsubsection{Single-mode distribution}

The particle-size distributions of $\mathrm{Na}^{+}, \mathrm{P}, \mathrm{K}^{+}, \mathrm{Ca}, \mathrm{Ti}$, and Ce showed a clear single coarse-mode distribution (Fig. 7). As conservative species in seawater, $\mathrm{Na}^{+}, \mathrm{K}^{+}$, and $\mathrm{Ca}$ were likely dominated by sea-salt aerosols and all had a coarse primary mode at approximately $2.5-4.4 \mu \mathrm{m}$. Such a pattern agrees well with the particle-size distributions of seasalt aerosols measured in coastal East Antarctica (Xu et al., 2013). Similarly, Ti and Ce derived from crustal emission were dominated by coarse-mode particles, peaking at around $4.4 \mu \mathrm{m}$. The aerosol $\mathrm{P}$ had a slightly shifted single-mode distribution and peaked between the coarse-mode crustal aerosol and the sea-salt aerosol at around 2.5-4.4 $\mu \mathrm{m}$. Consequently, $\mathrm{P}$ was likely controlled by a regional emission source, such as soil resuspension. Given that gravitational settling greatly limits the residence time of coarse-mode particles compared with fine-mode particles, the elements with single coarse-mode distribution are likely to have a relatively proximal dominant source, such as the ice-free areas in the Antarctic Peninsula during austral summer.

\subsubsection{Bimodal distribution}

Although $\mathrm{V}$ and $\mathrm{Mn}$ also had a single-mode distribution in most samples, bimodal distribution was found in a few samples, hinting at contributions from multiple sources (Fig. 8). The particle-size distribution of $\mathrm{V}$ and Mn primarily peaked around $4.4 \mu \mathrm{m}$, while a small fine-mode peak could be seen around $0.14-0.25 \mu \mathrm{m}$ in sample M2 and M4 for V, and a similar fine-mode peak is also present in M4 for Mn. A different Mn particle-size distribution was dominated by particles larger than $18 \mu \mathrm{m}$, which is similar to $\mathrm{Al}$ and will be discussed below in Sect. 3.3.3. As we concluded above, V and Mn were dominated by crustal emission, and the coarse primary mode indicates regional crustal sources. As the size of dust particles decreases with distance away from the sources due to the higher deposition rates of coarse particles (Duce et al., 1991; Baker and Jickells, 2006), the fine-mode peaks are likely caused by additional input from long-range transport. The particle-size distribution of $\mathrm{V}$ in $\mathrm{M} 2$ showed a unique peak in the fine-mode range. In addition, M2 had the highest concentrations of $\mathrm{Ni}$ and $\mathrm{Cu}$ among all the samples. The air mass back trajectories suggested a contribution from the South Pacific Ocean and coastal South America. This suggests that the fine-mode particles in M2 might be influenced by the remote anthropogenic emissions. By contrast, the air mass back trajectories for M4 directly passed the South American continent. An elevated $\mathrm{Pb}$ concentration and fine-mode peaks in $\mathrm{Al}$ and $\mathrm{Pb}$ size distributions were observed also in M4. Such results suggest M4 may have received polluted dust derived from South America.

\subsubsection{Trimodal distribution}

Aerosol $\mathrm{Pb}$ showed bimodal and trimodal distributions in this study (Fig. 8). Compared with the other elements, the primary mode of $\mathrm{Pb}$ was much finer and peaked at around $0.14-0.25 \mu \mathrm{m}$. The primary fine-mode fractions of aerosol $\mathrm{Pb}$ in some samples suggest that aerosol $\mathrm{Pb}$ at Palmer Station was occasionally dominated by anthropogenic sources as $\mathrm{Pb}$ is usually concentrated in fine particles from industrial or traffic emissions (Mamun et al., 2020). Air mass back trajectories also suggest the high $\mathrm{Pb}$ samples (M4, M5) received air mass derived from southern South America through long-range transport. The secondary mode of $\mathrm{Pb}$ was found around the same size as the crustal elements (approximately $4.4 \mu \mathrm{m}$ ), indicating a possible regional emission, including both crustal sources and local contaminated soil (Santos et al., 2005). In addition, a tertiary mode was observed in M4 and peaked around 0.78-1.4 $\mu \mathrm{m}$. Considering M4 was influenced by long-range transport, $\mathrm{Pb}$ in this size range may be dominated by distinct remote sources. Thus $\mathrm{Pb}$ 

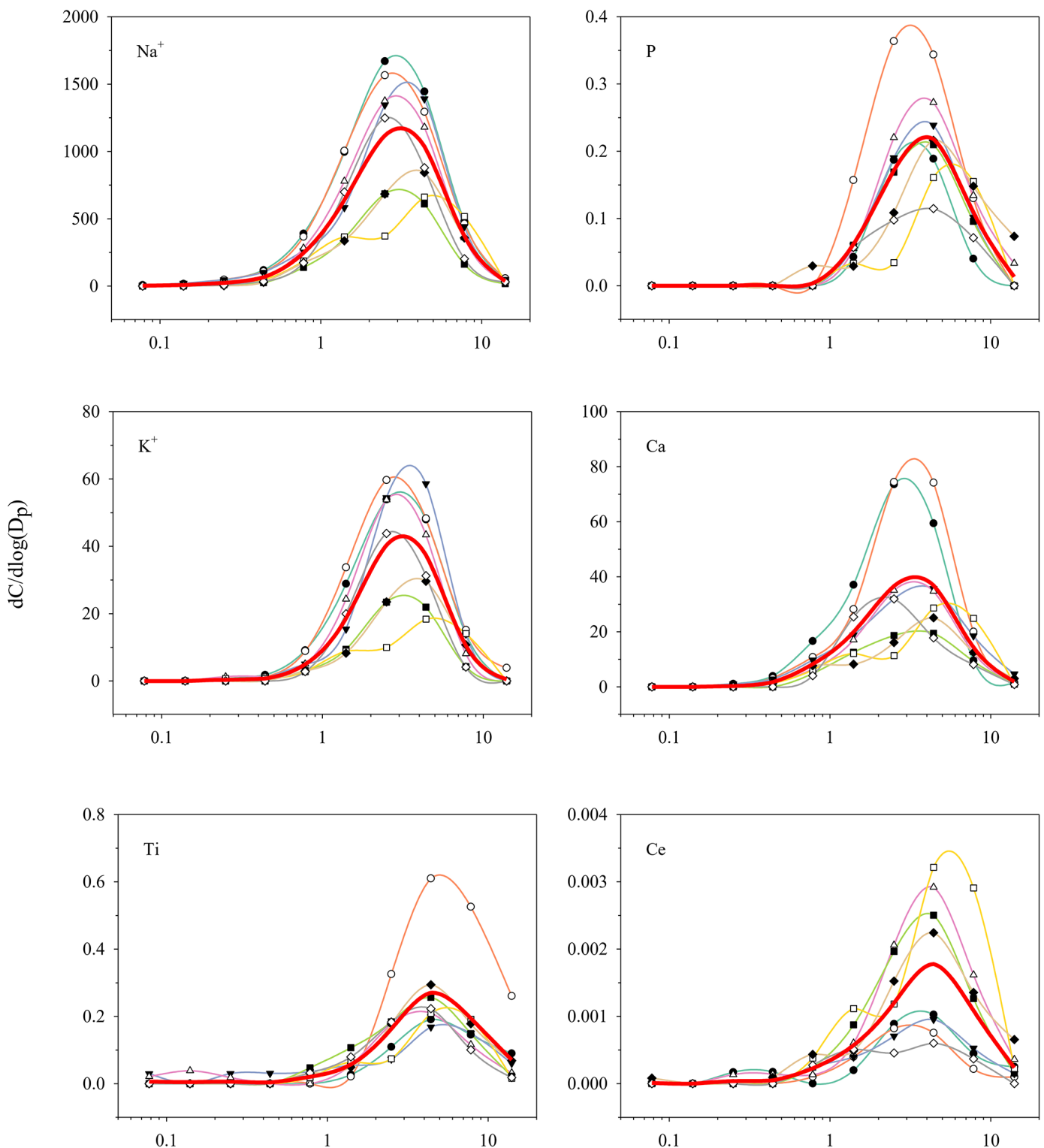

Aerosol particle size $\left(\mathrm{D}_{\mathrm{p}}, \mu \mathrm{m}\right)$

$\bullet \mathrm{M} 1 \multimap \mathrm{M} 2 \rightarrow \mathrm{M} 4 \multimap \mathrm{M} 5 \rightarrow \mathrm{M} 7 \rightarrow \mathrm{M} 8 \rightarrow \mathrm{M} 9 \multimap \mathrm{M} 10 \multimap$ Average

Figure 7. Particle-size distributions of the trace elements showing single-mode distribution in aerosols during November 2016-January 2017 austral summer over Palmer Station. $\mathrm{d} C / \mathrm{d} \log \left(D_{\mathrm{p}}\right)$ is the normalized concentration.

at Palmer Station was largely controlled by remote sources in South America. Because $\mathrm{Pb}$ was dominated by fine particles, an extremely small dry deposition velocity would be expected (Table 2). This might explain why previous studies in the Antarctic Peninsula suggested aerosol $\mathrm{Pb}$ was contributed by remote anthropogenic emission (Dick, 1991), whereas $\mathrm{Pb}$ in snow appeared to be associated with natural aerosols (Suttie and Wolff, 1992).

The average Al particle-size distribution showed trimodal distribution with a primary mode at particle size larger than
$18 \mu \mathrm{m}$, a secondary mode around $4.4 \mu \mathrm{m}$, and a tertiary mode around 0.14-0.25 $\mu \mathrm{m}$ (Fig. 8). A single-mode Al particle-size distribution peaked at around $4.4 \mu \mathrm{m}$, which shared the same size with the primary mode of $\mathrm{Ti}, \mathrm{V}, \mathrm{Mn}$, and $\mathrm{Ce}$ in samples M8 and M9, indicating the regional crustal emissions. An additional high peak ( $>18 \mu \mathrm{m}$ ) was found in M1, M2, and M7 that contributed to bimodal distribution. A similar distribution can be seen in the Mn distribution of M2. We speculate that high $\mathrm{Al}$ concentrations associated with large particles might be caused by local soil resuspension around 


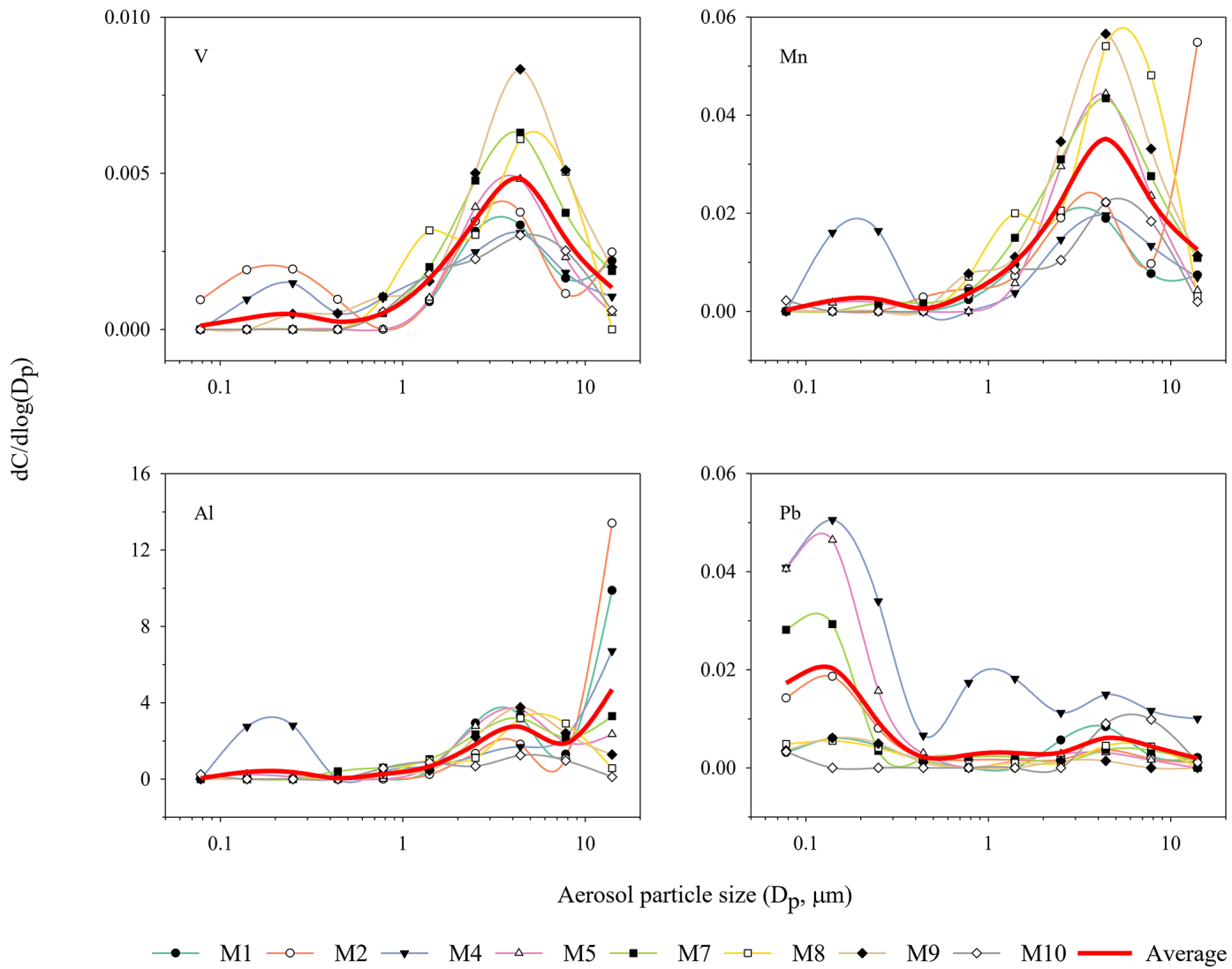

Figure 8. Particle-size distributions of the trace elements showing bimodal and trimodal distribution in aerosols during November 2016January 2017 austral summer over Palmer Station. $\mathrm{d} C / \mathrm{d} \log \left(D_{\mathrm{p}}\right)$ is the normalized concentration.

the sampling site, introducing large Al-containing particles that may come from aluminosilicate minerals. Such large Alcontaining particles may not be unusual, as large-size dust particles were found in Antarctic snow (Winton et al., 2016). Trimodal distribution involved another mode in fine particles, approximately $0.14-0.25 \mu \mathrm{m}$, in M4 and M5. The high fine-mode $\mathrm{Al}$ of M4 and M5 likely derives from long-range transport from South America, which matches with the two highest $\mathrm{Pb}$ concentrations in this study.

\subsubsection{Particle-size distribution of mineral dust in Antarctica}

Although the particle-size distributions of crustal elements (Al, Ti, V, Mn, Ce) have been reported only rarely for Antarctica, the particle-size distributions of mineral dust in aerosols, snow, and ice core samples were studied at several sites. The crustal aerosols sampled at Aboa research station, East Antarctica, had a single-mode distribution peaking at a particle size larger than $8.5 \mu \mathrm{m}$ (Virkkula et al., 2006). In addition, the grain size distribution of dust particles in snow collected at Berkner Island was largely dominated by particles larger than $5 \mu \mathrm{m}$, suggesting a significantly higher proportion of dust was in coarse mode than the previous size distribution observed at Kohnen Station, East Antarctic Plateau (Bory et al., 2010). Similarly, at Roosevelt Island, the particle-size distributions of dust particles in snow were primarily dominated by coarse particles, possibly larger than $9 \mu \mathrm{m}$ (Winton et al., 2016). Likewise, the dust particle-size distribution at Dome $\mathrm{C}$ during the Last Glacial Maximum and the Holocene showed single mode and peaked at approximately $2-3 \mu \mathrm{m}$ in ice core samples $(\sim 3233 \mathrm{~m}$ above sea level) (Delmonte et al., 2002; Potenza et al., 2016). Therefore, the dust particlesize distributions measured in coastal Antarctic regions are usually concentrated in coarse particles, whereas the dust particle-size distributions of inland Antarctic regions, with longer pathways from the sources, show peaks in relatively finer particles.

\subsection{Atmospheric dry deposition fluxes}

Aerosol particle-size distributions have been used to estimate atmospheric dry deposition fluxes of aerosol Fe to the Southern Ocean and coastal Antarctica (Gao et al., 2013, 2020). Similarly, the dry deposition fluxes of aerosol trace elements were estimated in this study (Table 3 ). Given that the sea-salt elements were the most abundant, Ca showed the highest dry deposition flux, which varied from 0.59 to $6.6 \mathrm{mg} \mathrm{m}^{-2} \mathrm{yr}^{-1}$ 
Table 3. Estimates of dry deposition velocities and dry deposition fluxes of trace elements in aerosols over Palmer Station, western Antarctic Peninsula.

\begin{tabular}{|c|c|c|c|c|c|}
\hline & \multirow[t]{2}{*}{ Element } & \multicolumn{2}{|c|}{ Velocity $\left(\mathrm{cm} \mathrm{s}^{-1}\right)$} & \multicolumn{2}{|c|}{ Flux $\left(\mu \mathrm{g} \mathrm{m}^{-2} \mathrm{yr}^{-1}\right)$} \\
\hline & & Range & Mean & Range & Mean \\
\hline & Dust & & & $650-28000$ & $5500 \pm 5100$ \\
\hline \multirow{6}{*}{$\mathrm{EF}<10$} & $\mathrm{Al}$ & $0.14-1.6$ & 0.49 & $52-2300$ & $440 \pm 410$ \\
\hline & $\mathrm{P}$ & $0.092-0.52$ & 0.17 & $3.3-33$ & $7.5 \pm 4.4$ \\
\hline & $\mathrm{Ti}$ & $0.14-0.92$ & 0.27 & $7.1-120$ & $18 \pm 15$ \\
\hline & V & $0.14-0.85$ & 0.26 & $0.16-0.77$ & $0.32 \pm 0.11$ \\
\hline & Mn & $0.18-1.1$ & 0.28 & $0.94-11$ & $2.5 \pm 1.6$ \\
\hline & $\mathrm{Ce}$ & $0.10-0.65$ & 0.20 & $0.017-0.31$ & $0.084 \pm 0.048$ \\
\hline \multirow{5}{*}{$\mathrm{EF}>10$} & $\mathrm{Ca}$ & $0.073-0.41$ & 0.13 & $580-6600$ & $1200 \pm 660$ \\
\hline & $\mathrm{Pb}$ & $0.0097-0.83$ & 0.11 & $0.018-1.5$ & $0.30 \pm 0.23$ \\
\hline & $\mathrm{Ni}^{*}$ & & $0.11-0.49$ & $3.9-17$ & \\
\hline & $\mathrm{Cu}^{*}$ & & $0.11-0.49$ & $6.0-25$ & \\
\hline & $\mathrm{Zn} *$ & & $0.11-0.49$ & $8.1-36$ & \\
\hline
\end{tabular}

* The range of dry deposition fluxes of $\mathrm{Ni}, \mathrm{Cu}$, and $\mathrm{Zn}$ was estimated based on $\mathrm{Pb}$ and $\mathrm{Al}$ dry deposition velocities, discussed in the text.

with an average of $1.2 \pm 0.7 \mathrm{mg} \mathrm{m}^{-2} \mathrm{yr}^{-1}$. At the other extreme, due to low concentration and fine-mode particle dominance, aerosol $\mathrm{Pb}$ showed $\sim 5000$-fold lower dry deposition fluxes with a mean of $0.30 \pm 0.23 \mu \mathrm{g} \mathrm{m}^{-2} \mathrm{yr}^{-1}$. The rough estimates of the dry deposition fluxes of $\mathrm{Ni}$ and $\mathrm{Zn}$ at Palmer Station are close to the median deposition fluxes found in the western North Atlantic Ocean (Ni: $18 \mu \mathrm{g} \mathrm{m}^{-2} \mathrm{yr}^{-1}$; $\mathrm{Zn}: 16 \mu \mathrm{g} \mathrm{m}^{-2} \mathrm{yr}^{-1}$ ), whereas the dry deposition flux of $\mathrm{Cu}$ is slightly higher than the median $\mathrm{Zn}$ dry deposition flux $\left(2.8 \mu \mathrm{g} \mathrm{m}^{-2} \mathrm{yr}^{-1}\right)$ in the western North Atlantic Ocean (Shelley et al., 2017). However, the dry deposition flux of $\mathrm{Cu}$ at Palmer Station is in the lower range of that observed in the eastern North Atlantic Ocean, 3.97-194 $\mu \mathrm{g} \mathrm{m}^{-2} \mathrm{yr}^{-1}$ (Buck et al., 2019). The estimated dry deposition fluxes of total continental dust at Palmer station ranged from 0.65 to $28 \mathrm{mg} \mathrm{m}^{-2} \mathrm{yr}^{-1}$ with a mean of $5.5 \pm 5.1 \mathrm{mg} \mathrm{m}^{-2} \mathrm{yr}^{-1}$, and this flux is only around $10 \%$ of the mean global dust deposition flux at remote sites (Lawrence and Neff, 2009). Previous modeling studies estimated that wet deposition of dust through precipitation scavenging accounted for about 40 $60 \%$ of the total deposition in the coastal and open oceans in the mid- and low-latitude oceans (Gao et al., 2003), and a similar wet deposition fraction was found in the Southern Ocean and coastal East Antarctica (Gao et al., 2013). Although precipitation varies in different regions, this is the best estimate we have for Antarctic regions. Assuming this wet deposition fraction (0.4-0.6) applies to the Antarctic Peninsula region, we approximate roughly a total dust flux of $10 \pm 10 \mathrm{mg} \mathrm{m}^{-2} \mathrm{yr}^{-1}$. This value is at the lower end of the dust flux range, $\sim 5$ to $\sim 50 \mathrm{mg} \mathrm{m}^{-2} \mathrm{yr}^{-1}$, estimated from ice core measurements at James Ross Island on the Antarctic Peninsula over the 20th century (McConnell et al., 2007), but it is higher than dust deposition flux at Dome C (0.2-
$0.6 \mathrm{mg} \mathrm{m}^{-2} \mathrm{yr}^{-1}$ ) (Lambert et al., 2012) and at Talos Dome (0.70-7.24 $\mathrm{mg} \mathrm{m}^{-2} \mathrm{yr}^{-1}$ ) (Albani et al., 2012) as well as the model estimate for this region $\left(1.8-3.7 \mathrm{mg} \mathrm{m}^{-2} \mathrm{yr}^{-1}\right.$ ) (Wagener et al., 2008). Considering active dust sources were reported at James Ross Island (Kavan et al., 2018), sites close to James Ross Island are likely to receive higher dust deposition fluxes. In addition, without measurements of wet deposition, the total dust deposition flux in our study could be underestimated. Compared with the global data, the dust deposition flux at Palmer Station is far lower than the total dust deposition fluxes in the North and South Atlantic Ocean (minimum of 270 and $150 \mathrm{mg} \mathrm{m}^{-2} \mathrm{yr}^{-1}$, respectively) (Menzel Barraqueta et al., 2019), South Pacific Ocean $\left(230 \mathrm{mg} \mathrm{m}^{-2} \mathrm{yr}^{-1}\right.$ ) (Prospero, 1989), South Indian Ocean $\left(240 \mathrm{mg} \mathrm{m}^{-2} \mathrm{yr}^{-1}\right)$ (Heimburger et al., 2012), and McMurdo Dry Valleys (490 $\mathrm{mg} \mathrm{m}^{-2} \mathrm{yr}^{-1}$ ) (Lancaster, 2002), while it is close to the estimated total dust deposition fluxes for the $63^{\circ} \mathrm{S}$ region (between $62^{\circ} 53^{\prime} \mathrm{S}$ and $63^{\circ} 53^{\prime} \mathrm{S}$, along $170^{\circ} 6^{\prime} \mathrm{W} ; 33 \mathrm{mg} \mathrm{m}^{-2} \mathrm{yr}^{-1}$ ) (Measures and Vink, 2000). Accordingly, the other crustal elements $(\mathrm{P}, \mathrm{Ti}, \mathrm{V}, \mathrm{Mn}, \mathrm{Ce})$ were proportional to the dust dry deposition flux and showed extremely low values.

To examine the potential importance of atmospheric dust input to the particulate elemental concentrations in surface waters of the western Antarctic Peninsula shelf region, the maximum possible suspended particulate $\mathrm{Al}$ concentrations in surface seawater contributed by dust were estimated. We used the maximum $\mathrm{Al}$ dry deposition flux of $2300 \mu \mathrm{g} \mathrm{m}^{-2} \mathrm{yr}^{-1}$ (Table 3), assumed that dry deposition accounted for $40 \%$ of total deposition (Gao et al., 2003), and assumed no settling loss from the mixed layer of mean depth $24 \mathrm{~m}$ (Eveleth et al., 2017) over a 4-month summer season. By this calculation, the accumulated concentration of sus- 
pended particulate $\mathrm{Al}$ contributed by total atmospheric deposition over this period is $3 \mathrm{nmol} \mathrm{kg}{ }^{-1}$. While suspended $\mathrm{Al}$ reaches $135 \mathrm{nmol} \mathrm{kg}^{-1}$ in coastal surface waters close to the peninsula, outer shelf and off-shelf surface waters generally have concentrations $<5 \mathrm{nmol} \mathrm{kg}^{-1}$ (Annett et al., 2017), suggesting that this upper-limit-estimated dust flux could account for a substantial portion of observed surface ocean lithogenic particle concentration. While the mean $\mathrm{Al}$ flux is just $20 \%$ of this maximum, and settling loss from the mixed layer over the course of the summer may be significant, it is also possible that the residence time of particulate $\mathrm{Al}$ in the surface layer exceeds the summer season, by analogy to the North Atlantic (Jickells, 1999), allowing greater accumulation and concentrations than our simple calculation indicates. This rough estimate suggests that atmospheric dust deposition, possibly dominated by regional sources on the Antarctic continent itself, may contribute a significant fraction of suspended particulate concentrations of lithogenic elements in the surface waters of the outer shelf and the proximal pelagic Southern Ocean.

\section{Conclusions and implications}

Results from this study indicate that trace elements in aerosols over Palmer Station during the austral summer were primarily derived from (1) the regional crustal sources, which includes P-enriched soil resuspension; (2) remote anthropogenic emissions in South America; and (3) seawater. Remote crustal sources and local contaminated soil may also contribute to aerosol trace elements at Palmer Station. The particle-size distributions of crustal elements - including Al, $\mathrm{P}, \mathrm{Ti}, \mathrm{V}, \mathrm{Mn}$, and $\mathrm{Ce}$ - were all concentrated in coarse mode, suggesting strong regional emissions likely from ice-free areas on the Antarctic Peninsula and its associated islands. In some samples, $\mathrm{Al}, \mathrm{V}$, and $\mathrm{Mn}$ also had a secondary peak in the fine-mode fraction, likely derived from a distinct source through long-range transport. We speculate that the modest enrichment of aerosol $\mathrm{P}$ over its crustal ratio to $\mathrm{Al}$ was caused by the resuspension of regional soils that are P-enriched as a result of the impact of nearby bird colonies. The elements $\mathrm{Ca}$, $\mathrm{Na}^{+}$, and $\mathrm{K}^{+}$had a single coarse-mode distribution, likely derived from sea salt. Conversely, the size distribution of $\mathrm{Pb}$ occurred primarily in fine mode. The air mass back trajectories show that samples with high concentrations of $\mathrm{Ni}, \mathrm{Cu}$, $\mathrm{Zn}$, and $\mathrm{Pb}$ were influenced by air masses passing through southern South America and the South Pacific Ocean. The total dust deposition flux $\left(\sim 10 \mathrm{mg} \mathrm{m}^{-2} \mathrm{yr}^{-1}\right)$ during austral summer, estimated from the $\mathrm{Al}$ concentrations obtained in this study and an assumption of relative wet deposition, suggests that dust deposition plays a minor role in the concentrations of trace elements in coastal seawater around the western Antarctic Peninsula but may be more important in offshore regions. As the role of wet deposition is unquantified at present and remains poorly constrained for this re- gion, the total deposition fluxes of trace elements during the austral summer could exceed the dry deposition fluxes reported here. Therefore, the importance of atmospheric deposition of trace elements to the coastal western Antarctic Peninsula may need to be re-evaluated with additional observations of wet deposition. The Antarctic Peninsula is experiencing rapid climate change, with the expansion of ice-free areas and more frequent shipboard tourism with unknown impacts on aerosol chemistry in this region. To quantify future changes in the atmospheric position and the impact in this region, long-term atmospheric observations of aerosol chemical and physical properties along with coupled studies of the ocean-atmosphere interactions would be needed.

Data availability. The data used in this paper have been submitted to the US Antarctic Program Data Center (https://doi.org/10.15784/601370, Gao, 2020).

Supplement. The supplement related to this article is available online at: https://doi.org/10.5194/acp-21-2105-2021-supplement.

Author contributions. YG conceived the research. YG and SY prepared field sampling and collected aerosol samples. SF and YG digested samples. KB and RMS conducted sample analyses. SF wrote the first draft of the manuscript. YG and RMS edited the drafts. All authors contributed to writing and approved the submission.

Competing interests. The authors declare that they have no conflict of interest.

Acknowledgements. We thank Hugh Ducklow for encouragement of this research; Rafael Jusino-Atresino, Pami Mukherjee, and Guojie $\mathrm{Xu}$ for participating in fieldwork preparation; and Jianqiong Zhan for assisting with meteorological data analyses. This work would not have become possible without the dedication and support from the staff of Palmer Station and the US Antarctic Program. We also appreciate the constructive comments from Holly Winton and an anonymous reviewer.

Financial support. This research was supported by the US National Science Foundation (grant no. OPP1341494 to Yuan Gao).

Review statement. This paper was edited by Leiming Zhang and reviewed by Holly Winton and one anonymous referee.

\section{References}

Abram, N. J., Mulvaney, R., Wolff, E. W., Triest, J., Kipfstuhl, S., Trusel, L. D., Vimeux, F., Fleet, L., and Arrowsmith, 
C.: Acceleration of snow melt in an Antarctic Peninsula ice core during the twentieth century, Nat. Geosci., 6, 404-411, https://doi.org/10.1038/ngeo1787, 2013.

Adebiyi, A. A. and Kok, J. F.: Climate models miss most of the coarse dust in the atmosphere, Sci. Adv., 6, eaaz9507, https://doi.org/10.1126/sciadv.aaz9507, 2020.

Albani, S., Delmonte, B., Maggi, V., Baroni, C., Petit, J.-R., Stenni, B., Mazzola, C., and Frezzotti, M.: Interpreting last glacial to Holocene dust changes at Talos Dome (East Antarctica): implications for atmospheric variations from regional to hemispheric scales, Clim. Past, 8, 741-750, https://doi.org/10.5194/cp-8-7412012, 2012.

Annett, A. L., Fitzsimmons, J. N., Séguret, M. J., Lagerström, M., Meredith, M. P., Schofield, O., and Sherrell, R. M.: Controls on dissolved and particulate iron distributions in surface waters of the Western Antarctic Peninsula shelf, Mar. Chem., 196, 81-97, 2017.

Arimoto, R., Zeng, T., Davis, D., Wang, Y., Khaing, H., Nesbit, C., and Huey, G.: Concentrations and sources of aerosol ions and trace elements during ANTCI-2003, Atmos. Environ., 42, 2864 2876, 2008.

Aristarain, A. J., Delmas, R. J., and Briat, M.: Snow chemistry on James Ross Island (Antarctic Peninsula), J. Geophys. Res.Ocean., 87, 11004-11012, 1982.

Artaxo, P., Andrade, F., and Maenhaut, W.: Trace elements and receptor modelling of aerosols in the Antarctic Peninsula, Nucl. Instrum. Meth. B, 49, 383-387, 1990.

Artaxo, P., Rabello, M. L., Maenhaut, W., and Grieken, R. V.: Trace elements and individual particle analysis of atmospheric aerosols from the Antarctic Peninsula, Tellus B, 44, 318-334, 1992.

Artaxo, P., Oyola, P., and Martinez, R.: Aerosol composition and source apportionment in Santiago de Chile, Nucl. Instrum. Meth. B, 150, 409-416, 1999.

Asmi, E., Neitola, K., Teinilä, K., Rodriguez, E., Virkkula, A., Backman, J., Bloss, M., Jokela, J., Lihavainen, H., and De Leeuw, G.: Primary sources control the variability of aerosol optical properties in the Antarctic Peninsula, Tellus B, 70, 1-16, 2018.

Baker, A. and Jickells, T.: Mineral particle size as a control on aerosol iron solubility, Geophys. Res. Lett., 33, L17608, https://doi.org/10.1029/2006GL026557, 2006.

Baker, A. R., Li, M., and Chance, R.: Trace metal fractional solubility in size-segregated aerosols from the tropical eastern Atlantic Ocean, Glob. Biogeochem. Cy., 34, e2019GB006510, https://doi.org/10.1029/2019GB006510, 2020.

Blecker, S., Ippolito, J., Barrett, J., Wall, D., Virginia, R., and Norvell, K.: Phosphorus fractions in soils of Taylor Valley, Antarctica, Soil Sci. Soc. Am. J., 70, 806-815, 2006.

Bockheim, J., Vieira, G., Ramos, M., López-Martínez, J., Serrano, E., Guglielmin, M., Wilhelm, K., and Nieuwendam, A.: Climate warming and permafrost dynamics in the Antarctic Peninsula region, Glob. Planet. Change, 100, 215-223, 2013.

Boës, X., Rydberg, J., Martinez-Cortizas, A., Bindler, R., and Renberg, I.: Evaluation of conservative lithogenic elements (Ti, Zr, $\mathrm{Al}$, and $\mathrm{Rb}$ ) to study anthropogenic element enrichments in lake sediments, J. Paleolimnol., 46, 75-87, 2011.

Bollhöfer, A. F., Rosman, K. J. R., Dick, A. L., Chisholm, W., Burton, G. R., Loss, R. D., and Zahorowski, W.: Concentration, isotopic composition, and sources of lead in Southern Ocean air during 1999/2000, measured at the Cape Grim Baseline Air Pollution Station, Tasmania, Geochim. Cosmochim. Ac., 69, 47474757, https://doi.org/10.1016/j.gca.2005.06.024, 2005.

Bory, A., Wolff, E., Mulvaney, R., Jagoutz, E., Wegner, A., Ruth, U., and Elderfield, H.: Multiple sources supply eolian mineral dust to the Atlantic sector of coastal Antarctica: Evidence from recent snow layers at the top of Berkner Island ice sheet, Earth Planet. Sci. Lett., 291, 138-148, 2010.

Boutron, C. and Lorius, C.: Trace metals in Antarctic snows since 1914, Nature, 277, 551-554, https://doi.org/10.1038/277551a0, 1979.

Bridgestock, L., Van De Flierdt, T., Rehkämper, M., Paul, M., Middag, R., Milne, A., Lohan, M. C., Baker, A. R., Chance, R., and Khondoker, R.: Return of naturally sourced $\mathrm{Pb}$ to Atlantic surface waters, Nat. Commun., 7, 1-12, 2016.

Bromwich, D. H., Nicolas, J. P., Monaghan, A. J., Lazzara, M. A., Keller, L. M., Weidner, G. A., and Wilson, A. B.: Central West Antarctica among the most rapidly warming regions on Earth, Nat. Geosci., 6, 139-145, https://doi.org/10.1038/ngeo1671, 2013.

Buck, C. S., Landing, W. M., and Resing, J. A.: Particle size and aerosol iron solubility: A high-resolution analysis of Atlantic aerosols, Mar. Chem., 120, 14-24, 2010.

Buck, C. S., Aguilar-Islas, A., Marsay, C., Kadko, D., and Landing, W. M.: Trace element concentrations, elemental ratios, and enrichment factors observed in aerosol samples collected during the US GEOTRACES eastern Pacific Ocean transect (GP16), Chem. Geol., 511, 212-224, 2019.

Caliński, T. and Harabasz, J.: A dendrite method for cluster analysis, Commun. Stat. Theor. M., 3, 1-27, 1974.

Campbell, I. B. and Claridge, G.: Antarctica: soils, weathering processes and environment, Elsevier, Amsterdam, 1987.

Carrasco, M. A. and Préndez, M.: Element distribution of some soils of continental Chile and the Antarctic peninsula. Projection to atmospheric pollution, Water Air Soil Pollut., 57, 713-722, 1991.

Celo, V., Dabek-Zlotorzynska, E., and McCurdy, M.: Chemical characterization of exhaust emissions from selected Canadian marine vessels: the case of trace metals and lanthanoids, Environ. Sci. Technol., 49, 5220-5226, 2015.

Chambers, S. D., Hong, S.-B., Williams, A. G., Crawford, J., Griffiths, A. D., and Park, S.-J.: Characterising terrestrial influences on Antarctic air masses using Radon-222 measurements at King George Island, Atmos. Chem. Phys., 14, 9903-9916, https://doi.org/10.5194/acp-14-9903-2014, 2014.

Chen, Y.: Sources and fate of atmospheric nutrients over the remote oceans and their role on controlling marine diazotrophic microorganisms, Doctoral dissertation, available at: https://drum. lib.umd.edu/handle/1903/1967 (last access: 29 January 2021), 2004.

Chen, Y. and Siefert, R. L.: Seasonal and spatial distributions and dry deposition fluxes of atmospheric total and labile iron over the tropical and subtropical North Atlantic Ocean, J. Geophys. Res.Atmos., 109, D09305, https://doi.org/10.1029/2003JD003958, 2004.

Chuang, P., Duvall, R., Shafer, M., and Schauer, J.: The origin of water soluble particulate iron in the Asian atmospheric outflow, Geophys. Res. Lett., 32, L07813, https://doi.org/10.1029/2004GL021946, 2005. 
Cook, A. J., Holland, P., Meredith, M., Murray, T., Luckman, A., and Vaughan, D. G.: Ocean forcing of glacier retreat in the western Antarctic Peninsula, Science, 353, 283-286, 2016.

Crusius, J., Schroth, A. W., Gasso, S., Moy, C. M., Levy, R. C., and Gatica, M.: Glacial flour dust storms in the Gulf of Alaska: Hydrologic and meteorological controls and their importance as a source of bioavailable iron, Geophys. Res. Lett., 38, L06602, https://doi.org/10.1029/2010GL046573, 2011.

Delmonte, B., Petit, J., and Maggi, V.: Glacial to Holocene implications of the new 27 000-year dust record from the EPICA Dome C (East Antarctica) ice core, Clim. Dynam., 18, 647-660, 2002.

Delmonte, B., Winton, H., Baroni, M., Baccolo, G., Hansson, M., Andersson, P., Baroni, C., Salvatore, M. C., Lanci, L., and Maggi, V.: Holocene dust in East Antarctica: Provenance and variability in time and space, Holocene, 30, 546-558, https://doi.org/10.1177/0959683619875188, 2020.

Dick, A.: Concentrations and sources of metals in the Antarctic Peninsula aerosol, Geochim. Cosmochim. Ac., 55, 1827-1836, 1991.

Dick, A. and Peel, D.: Trace elements in Antarctic air and snowfall, Ann. Glaciol., 7, 12-19, 1985.

Duce, R., Liss, P., Merrill, J., Atlas, E., Buat-Menard, P., Hicks, B., Miller, J., Prospero, J., Arimoto, R., and Church, T.: The atmospheric input of trace species to the world ocean, Glob. Biogeochem. Cy., 5, 193-259, 1991.

Duce, R. A. and Tindale, N. W.: Atmospheric transport of iron and its deposition in the ocean, Limnol. Oceanogr., 36, 1715-1726, 1991.

Eveleth, R., Cassar, N., Sherrell, R., Ducklow, H., Meredith, M., Venables, H., Lin, Y., and Li, Z.: Ice melt influence on summertime net community production along the Western Antarctic Peninsula, Deep-Sea Res. Pt. II, 139, 89-102, 2017.

Fomba, K. W., Müller, K., van Pinxteren, D., and Herrmann, H.: Aerosol size-resolved trace metal composition in remote northern tropical Atlantic marine environment: case study Cape Verde islands, Atmos. Chem. Phys., 13, 4801-4814, https://doi.org/10.5194/acp-13-4801-2013, 2013.

Gantt, B., Hoque, S., Willis, R. D., Fahey, K. M., Delgado-Saborit, J. M., Harrison, R. M., Erdakos, G. B., Bhave, P. V., Zhang, K. M., and Kovalcik, K.: Near-road modeling and measurement of cerium-containing particles generated by nanoparticle diesel fuel additive use, Environ. Sci. Technol., 48, 10607-10613, 2014.

Gao, Y.: Concentrations and Particle Size Distributions of Aerosol Trace Elements, U.S. Antarctic Program (USAP) Data Center, https://doi.org/10.15784/601370, 2020.

Gao, Y., Fan, S., and Sarmiento, J.: Aeolian iron input to the ocean through precipitation scavenging: A modeling perspective and its implication for natural iron fertilization in the ocean, J. Geophys. Res.-Atmos., 108, 4221, https://doi.org/10.1029/2002JD002420, 2003

Gao, Y., Xu, G., Zhan, J., Zhang, J., Li, W., Lin, Q., Chen, L., and Lin, H.: Spatial and particle size distributions of atmospheric dissolvable iron in aerosols and its input to the Southern Ocean and coastal East Antarctica, J. Geophys. Res.-Atmos., 118, 1263412648, https://doi.org/10.1002/2013jd020367, 2013.

Gao, Y., Marsay, C. M., Yu, S., Fan, S., Mukherjee, P., Buck, C. S., and Landing, W. M.: Particle-Size Variability of Aerosol Iron and Impact on Iron Solubility and Dry Deposition Fluxes to the Arctic Ocean, Sci. Rep.-UK, 9, 1-11, 2019.
Gao, Y., Yu, S., Sherrell, R. M., Fan, S., Bu, K., and Anderson, J. R.: Particle-Size Distributions and Solubility of Aerosol Iron Over the Antarctic Peninsula During Austral Summer, J. Geophys. Res.-Atmos., 125, e2019JD032082, https://doi.org/10.1029/2019jd032082, 2020.

Gras, J.: CN, CCN and particle size in Southern Ocean air at Cape Grim, Atmos. Res., 35, 233-251, 1995.

Guieu, C., Bonnet, S., Wagener, T., and Loÿe-Pilot, M. D.: Biomass burning as a source of dissolved iron to the open ocean?, Geophys. Res. Lett., 32, L19608, https://doi.org/10.1029/2005GL022962, 2005.

Heimburger, A., Losno, R., Triquet, S., Dulac, F., and Mahowald, N.: Direct measurements of atmospheric iron, cobalt, and aluminum-derived dust deposition at Kerguelen Islands, Glob. Biogeochem. Cy., 26, GB4016, https://doi.org/10.1029/2012GB004301, 2012.

Herenz, P., Wex, H., Mangold, A., Laffineur, Q., Gorodetskaya, I. V., Fleming, Z. L., Panagi, M., and Stratmann, F.: CCN measurements at the Princess Elisabeth Antarctica research station during three austral summers, Atmos. Chem. Phys., 19, 275-294, https://doi.org/10.5194/acp-19-275-2019, 2019.

Hong, S., Kang, C. Y., and Kang, J.: Lichen Biomonitoring for the Detection of Local Heavy Metal Pollution around King Sejong Station, King George Island, Antarctica, Korean J. Polar Res., 10, 17-24, 1999.

Järvinen, E., Virkkula, A., Nieminen, T., Aalto, P. P., Asmi, E., Lanconelli, C., Busetto, M., Lupi, A., Schioppo, R., Vitale, V., Mazzola, M., Petäjä, T., Kerminen, V.-M., and Kulmala, M.: Seasonal cycle and modal structure of particle number size distribution at Dome C, Antarctica, Atmos. Chem. Phys., 13, 7473-7487, https://doi.org/10.5194/acp-13-7473-2013, 2013.

Jasan, R., Plá, R., Invernizzi, R., and Dos Santos, M.: Characterization of atmospheric aerosol in Buenos Aires, Argentina, J. Radioanal. Nucl. Ch., 281, 101-105, 2009.

Jickells, T. D.: The inputs of dust derived elements to the Sargasso Sea; a synthesis, Marine Chem., 68, 5-14, 1999.

Jickells, T. and Moore, C. M.: The importance of atmospheric deposition for ocean productivity, Annu. Rev. Ecol. Evol. S., 46, 481-501, 2015.

Jickells, T., Baker, A., and Chance, R.: Atmospheric transport of trace elements and nutrients to the oceans, Philos. T. R. Soc. A., 374, 20150286, https://doi.org/10.1098/rsta.2015.0286, 2016.

Kaufman, Y. J., Tanré, D., and Boucher, O.: A satellite view of aerosols in the climate system, Nature, 419, 215-223, 2002.

Kavan, J., Dagsson-Waldhauserova, P., Renard, J.-B., Laska, K., and Ambrožová, K.: Aerosol concentrations in relationship to local atmospheric conditions on James Ross Island, Antarctica, Front. Earth Sci., 6, https://doi.org/10.3389/feart.2018.00207, 2018.

Keywood, M., Hibberd, M. F., Selleck, P. W., Desservettaz, M., Cohen, D. D., Stelcer, E., Atanacio, A. J., Scorgie, Y., and Tzu-Chi Chang, L.: Sources of Particulate Matter in the Hunter Valley, New South Wales, Australia, Atmosphere-Basel, 11, 4, https://doi.org/10.3390/atmos11010004, 2020.

Kim, J., Yoon, Y. J., Gim, Y., Kang, H. J., Choi, J. H., Park, K.-T., and Lee, B. Y.: Seasonal variations in physical characteristics of aerosol particles at the King Sejong Station, Antarctic Peninsula, Atmos. Chem. Phys., 17, 12985-12999, https://doi.org/10.5194/acp-17-12985-2017, 2017. 
Klumpp, A., Domingos, M., and Pignata, M. L.: Air pollution and vegetation damage in South America-state of knowledge and perspectives, CRC Press LLC, USA, 2000.

Lachlan-Cope, T., Beddows, D. C. S., Brough, N., Jones, A. E., Harrison, R. M., Lupi, A., Yoon, Y. J., Virkkula, A., and Dall'Osto, M.: On the annual variability of Antarctic aerosol size distributions at Halley Research Station, Atmos. Chem. Phys., 20, 44614476, https://doi.org/10.5194/acp-20-4461-2020, 2020.

Lambert, F., Bigler, M., Steffensen, J. P., Hutterli, M., and Fischer, H.: Centennial mineral dust variability in high-resolution ice core data from Dome C, Antarctica, Clim. Past, 8, 609-623, https://doi.org/10.5194/cp-8-609-2012, 2012.

Lambert, G., Ardouin, B., and Sanak, J.: Atmospheric transport of trace elements toward Antarctica, Tellus B, 42, 76-82, 1990.

Lancaster, N.: Flux of eolian sediment in the McMurdo Dry Valleys, Antarctica: a preliminary assessment, Arct. Antarct. Alp. Res., 34, 318-323, 2002.

Lawrence, C. R. and Neff, J. C.: The contemporary physical and chemical flux of aeolian dust: A synthesis of direct measurements of dust deposition, Chem. Geol., 267, 46-63, 2009.

Li, F., Ginoux, P., and Ramaswamy, V.: Distribution, transport, and deposition of mineral dust in the Southern Ocean and Antarctica: Contribution of major sources, J. Geophys. Res., 113, D18217, https://doi.org/10.1029/2007jd009190, 2008.

Loureiro, A., Vasconcellos, M., and Pereira, E.: Trace element determination in aerosols from the Antarctic Peninsula by neutron activation analysis, J. Radioanal. Nucl. Ch., 159, 21-28, 1992.

Lowenthal, D. H., Chow, J. C., Mazzera, D. M., Watson, J. G., and Mosher, B. W.: Aerosol vanadium at McMurdo Station, Antarctica:: implications for Dye 3, Greenland, Atmos. Environ., 34, 677-679, 2000.

Lynch, H., Crosbie, K., Fagan, W., and Naveen, R.: Spatial patterns of tour ship traffic in the Antarctic Peninsula region, Antarct. Sci., 22, 123-130, 2010.

Maenhaut, W., Zoller, W. H., Duce, R. A., and Hoffman, G. L.: Concentration and size distribution of particulate trace elements in the south polar atmosphere, J. Geophys. Res.-Ocean., 84, 24212431, 1979.

Mahowald, N. M., Hamilton, D. S., Mackey, K. R., Moore, J. K., Baker, A. R., Scanza, R. A., and Zhang, Y.: Aerosol trace metal leaching and impacts on marine microorganisms, Nat. Commun., 9, 2614, https://doi.org/10.1038/s41467-018-04970-7, 2018.

Mamun, A. A., Cheng, I., Zhang, L., Dabek-Zlotorzynska, E., and Charland, J.-P.: Overview of size distribution, concentration, and dry deposition of airborne particulate elements measured worldwide, Environ. Rev., 28, 77-88, 2020.

Marsay, C. M., Kadko, D., Landing, W. M., Morton, P. L., Summers, B. A., and Buck, C. S.: Concentrations, provenance and flux of aerosol trace elements during US GEOTRACES Western Arctic cruise GN01, Chem. Geol., 502, 1-14, 2018.

Mazzera, D. M., Lowenthal, D. H., Chow, J. C., Watson, J. G., and GrubľEsíc, V.: PM10 measurements at McMurdo station, Antarctica, Atmos. Environ., 35, 1891-1902, 2001.

McConnell, J. R., Aristarain, A. J., Banta, J. R., Edwards, P. R., and Simões, J. C.: 20th-Century doubling in dust archived in an Antarctic Peninsula ice core parallels climate change and desertification in South America, P. Natl. Acad. Sci. USA, 104, 57435748, 2007.
McConnell, J. R., Maselli, O. J., Sigl, M., Vallelonga, P., Neumann, T., Anschütz, H., Bales, R. C., Curran, M. A. J., Das, S. B., Edwards, R., Kipfstuhl, S., Layman, L., and Thomas, E. R.: Antarctic-wide array of high-resolution ice core records reveals pervasive lead pollution began in 1889 and persists today, Sci. Rep.-UK, 4, 5848, https://doi.org/10.1038/srep05848, 2014.

Measures, C. and Vink, S.: On the use of dissolved aluminum in surface waters to estimate dust deposition to the ocean, Glob. Biogeochem. Cy., 14, 317-327, 2000.

Menzel Barraqueta, J.-L., Klar, J. K., Gledhill, M., Schlosser, C., Shelley, R., Planquette, H. F., Wenzel, B., Sarthou, G., and Achterberg, E. P.: Atmospheric deposition fluxes over the Atlantic Ocean: a GEOTRACES case study, Biogeosciences, 16, 1525-1542, https://doi.org/10.5194/bg-16-1525-2019, 2019.

Millero, F. J.: Chemical oceanography, CRC Press, Boca Raton, FL, 2016.

Mishra, V. K., Kim, K.-H., Hong, S., and Lee, K.: Aerosol composition and its sources at the King Sejong Station, Antarctic peninsula, Atmos. Environ., 38, 4069-4084, 2004.

Moore, C. M., Mills, M. M., Arrigo, K. R., Berman-Frank, I., Bopp, L., Boyd, P. W., Galbraith, E. D., Geider, R. J., Guieu, C., Jaccard, S. L., Jickells, T. D., La Roche, J., Lenton, T. M., Mahowald, N. M., Marañón, E., Marinov, I., Moore, J. K., Nakatsuka, T., Oschlies, A., Saito, M. A., Thingstad, T. F., Tsuda, A., and Ulloa, O.: Processes and patterns of oceanic nutrient limitation, Nat. Geosci., 6, 701-710, https://doi.org/10.1038/ngeo1765, 2013.

Mouri, H., Nagao, I., Okada, K., Koga, S., and Tanaka, H.: Elemental compositions of individual aerosol particles collected over the Southern Ocean: A case study, Atmos. Res., 43, 183-195, 1997.

Orr, A., Marshall, G. J., Hunt, J. C., Sommeria, J., Wang, C.-G., Van Lipzig, N. P., Cresswell, D., and King, J. C.: Characteristics of summer airflow over the Antarctic Peninsula in response to recent strengthening of westerly circumpolar winds, J. Atmos. Sci., 65, 1396-1413, 2008.

Otero, X. L., De La Peña-Lastra, S., Pérez-Alberti, A., Ferreira, T. O., and Huerta-Diaz, M. A.: Seabird colonies as important global drivers in the nitrogen and phosphorus cycles, Nat. Commun., 9, 246, https://doi.org/10.1038/s41467-017-02446-8, 2018.

Pacyna, J. M. and Pacyna, E. G.: An assessment of global and regional emissions of trace metals to the atmosphere from anthropogenic sources worldwide, Environ. Rev., 9, 269-298, 2001.

Pilinis, C., Pandis, S. N., and Seinfeld, J. H.: Sensitivity of direct climate forcing by atmospheric aerosols to aerosol size and composition, J. Geophys. Res.-Atmos., 100, 18739-18754, 1995.

Potenza, M., Albani, S., Delmonte, B., Villa, S., Sanvito, T., Paroli, B., Pullia, A., Baccolo, G., Mahowald, N., and Maggi, V.: Shape and size constraints on dust optical properties from the Dome C ice core, Antarctica, Sci. Rep.-UK, 6, 1-9, 2016.

Préndez, M., Wachter, J., Vega, C., Flocchini, R. G., Wakayabashi, P., and Morales, J. R.: $\mathrm{PM}_{2.5}$ aerosols collected in the Antarctic Peninsula with a solar powered sampler during austral summer periods, Atmos. Environ., 43, 5575-5578, https://doi.org/10.1016/j.atmosenv.2009.07.030, 2009.

Prietzel, J., Prater, I., Hurtarte, L. C. C., Hrbáček, F., Klysubun, W., and Mueller, C. W.: Site conditions and vegetation determine phosphorus and sulfur speciation in soils of Antarctica, Geochim. Cosmochim. Ac., 246, 339-362, 2019. 
Prospero, J., Barrett, K., Church, T., Dentener, F., Duce, R., Galloway, J., Levy, H., Moody, J., and Quinn, P.: Atmospheric deposition of nutrients to the North Atlantic Basin, Biogeochemistry, 35, 27-73, https://doi.org/10.1007/BF02179824, 1996.

Prospero, J. M.: Mineral aerosol transport to the Pacific Ocean, Chem. Oceanogr., 10, 188-218, 1989.

Quinn, T. and Ondov, J.: Influence of temporal changes in relative humidity on dry deposition velocities and fluxes of aerosol particles bearing trace elements, Atmos. Environ., 32, 3467-3479, 1998.

Rolph, G., Stein, A., and Stunder, B.: Real-time environmental applications and display sYstem: READY, Environ. Model. Softw., 95, 210-228, 2017.

Saltzman, E. S.: Marine aerosols, Geoph. Monograph Series, 187, 17-35, 2009.

Santos, I. R., Silva-Filho, E. V., Schaefer, C. E., Albuquerque-Filho, M. R., and Campos, L. S.: Heavy metal contamination in coastal sediments and soils near the Brazilian Antarctic Station, King George Island, Mar. Pollut. Bull., 50, 185-194, 2005.

Shelley, R. U., Morton, P. L., and Landing, W. M.: Elemental ratios and enrichment factors in aerosols from the US-GEOTRACES North Atlantic transects, Deep-Sea Res. Pt. II, 116, 262-272, 2015.

Shelley, R. U., Roca-Martí, M., Castrillejo, M., Sanial, V., Masqué, P., Landing, W. M., van Beek, P., Planquette, H., and Sarthou, G.: Quantification of trace element atmospheric deposition fluxes to the Atlantic Ocean ( $>40 \mathrm{~N}$; GEOVIDE, GEOTRACES GA01) during spring 2014, Deep-Sea Res. Pt. I, 119, 34-49, 2017.

Siefert, R. L., Johansen, A. M., and Hoffmann, M. R.: Chemical characterization of ambient aerosol collected during the southwest monsoon and intermonsoon seasons over the Arabian Sea: Labile-Fe (II) and other trace metals, J. Geophys. Res.-Atmos., 104, 3511-3526, 1999.

Suttie, E. D. and Wolff, E. W.: Seasonal input of heavy metals to Antarctic snow, Tellus B, 44, 351-357, https://doi.org/10.1034/j.1600-0889.1992.00012.x, 1992.

Taylor, S. R. and McLennan, S. M.: The geochemical evolution of the continental crust, Rev. Geophys., 33, 241-265, 1995.

Trabelsi, A., Masmoudi, M., Quisefit, J., and Alfaro, S.: Compositional variability of the aerosols collected on Kerkennah Islands (central Tunisia), Atmos. Res., 169, 292-300, 2016.

Tuncel, G., Aras, N. K., and Zoller, W. H.: Temporal variations and sources of elements in the South Pole atmosphere: 1 . Nonenriched and moderately enriched elements, J. Geophys. Res.Atmos., 94, 13025-13038, 1989.

Turner, J., Barrand, N. E., Bracegirdle, T. J., Convey, P., Hodgson, D. A., Jarvis, M., Jenkins, A., Marshall, G., Meredith, M. P., and Roscoe, H.: Antarctic climate change and the environment: an update, Polar Rec., 50, 237-259, 2014.

Van Lipzig, N., King, J., Lachlan-Cope, T., and Van den Broeke, M.: Precipitation, sublimation, and snow drift in the Antarctic Peninsula region from a regional atmospheric model, J. Geophys. Res.Atmos., 109, D24106, https://doi.org/10.1029/2004JD004701, 2004.

Vaughan, D. G., Marshall, G. J., Connolley, W. M., Parkinson, C., Mulvaney, R., Hodgson, D. A., King, J. C., Pudsey, C. J., and Turner, J.: Recent rapid regional climate warming on the Antarctic Peninsula, Clim. Change, 60, 243-274, 2003.
Viana, M., Amato, F., Alastuey, A. s., Querol, X., Moreno, T., García Dos Santos, S. 1., Herce, M. D., and Fernández-Patier, R.: Chemical tracers of particulate emissions from commercial shipping, Environ. Sci. Technol., 43, 7472-7477, 2009.

Viana, M., Hammingh, P., Colette, A., Querol, X., Degraeuwe, B., de Vlieger, I., and Van Aardenne, J.: Impact of maritime transport emissions on coastal air quality in Europe, Atmos. Environ., 90, 96-105, 2014.

Virkkula, A., Teinilä, K., Hillamo, R., Kerminen, V. M., Saarikoski, S., Aurela, M., Koponen, I. K., and Kulmala, M.: Chemical size distributions of boundary layer aerosol over the Atlantic Ocean and at an Antarctic site, J. Geophys. Res.-Atmos., 111, D05306, https://doi.org/10.1029/2004JD004958, 2006.

Wagener, T., Guieu, C., Losno, R., Bonnet, S., and Mahowald, N.: Revisiting atmospheric dust export to the Southern Hemisphere ocean: Biogeochemical implications, Glob. Biogeochem. Cy., 22, GB2006, https://doi.org/10.1029/2007gb002984, 2008.

Warneck, P.: Chapter 7 The Atmospheric Aerosol, in: International Geophysics, edited by: Warneck, P., Academic Press, Cambridge, MA, 278-373, https://doi.org/10.1016/S00746142(08)60634-8, 1988.

Weinzierl, B., Ansmann, A., Prospero, J., Althausen, D., Benker, N., Chouza, F., Dollner, M., Farrell, D., Fomba, W., and Freudenthaler, V.: The Saharan aerosol long-range transport and aerosolcloud-interaction experiment: overview and selected highlights, B. Am. Meteorol. Soc., 98, 1427-1451, 2017.

Weller, R., Wöltjen, J., Piel, C., Resenberg, R., Wagenbach, D., König-Langlo, G., and Kriews, M.: Seasonal variability of crustal and marine trace elements in the aerosol at Neumayer station, Antarctica, Tellus B, 60, 742-752, 2008.

Williams, R. M.: A model for the dry deposition of particles to natural water surfaces, Atmos. Environ., 16, 1933-1938, 1982.

Winton, V., Dunbar, G., Bertler, N., Millet, M. A., Delmonte, B., Atkins, C., Chewings, J., and Andersson, P.: The contribution of aeolian sand and dust to iron fertilization of phytoplankton blooms in southwestern Ross Sea, Antarctica, Glob. Biogeochem. Cy., 28, 423-436, 2014.

Winton, V., Edwards, R., Delmonte, B., Ellis, A., Andersson, P., Bowie, A., Bertler, N., Neff, P., and Tuohy, A.: Multiple sources of soluble atmospheric iron to Antarctic waters, Glob. Biogeochem. Cy., 30, 421-437, 2016.

Winton, V. H. L., Bowie, A. R., Edwards, R., Keywood, M., Townsend, A. T., van der Merwe, P., and Bollhöfer, A.: Fractional iron solubility of atmospheric iron inputs to the Southern Ocean, Mar. Chem., 177, 20-32, https://doi.org/10.1016/j.marchem.2015.06.006, 2015.

$\mathrm{Wu}, \mathrm{J}$. and Boyle, E. A.: Lead in the western North Atlantic Ocean: completed response to leaded gasoline phaseout, Geochim. Cosmochim. Ac., 61, 3279-3283, 1997.

$\mathrm{Xu}, \mathrm{G}$. and Gao, Y.: Atmospheric trace elements in aerosols observed over the Southern Ocean and coastal East Antarctica, Polar Res., 33, 23973, https://doi.org/10.3402/polar.v33.23973, 2014.

Xu, G., Gao, Y., Lin, Q., Li, W., and Chen, L.: Characteristics of water-soluble inorganic and organic ions in aerosols over the Southern Ocean and coastal East Antarctica during austral summer, J. Geophys. Res.-Atmos., 118, 13303-13318, 2013. 
Zhao, R., Han, B., Lu, B., Zhang, N., Zhu, L., and Bai, Z.: Element composition and source apportionment of atmospheric aerosols over the China Sea, Atmos. Pollut. Res., 6, 191-201, 2015.

Zhao, Y. and Gao, Y.: Mass size distributions of water-soluble inorganic and organic ions in size-segregated aerosols over metropolitan Newark in the US east coast, Atmos. Environ., 42, 4063-4078, 2008.

Zhu, C., Kawamura, K., and Kunwar, B.: Effect of biomass burning over the western North Pacific Rim: wintertime maxima of anhydrosugars in ambient aerosols from Okinawa, Atmos. Chem. Phys., 15, 1959-1973, https://doi.org/10.5194/acp-151959-2015, 2015.
Zhu, R., Kong, D., Sun, L., Geng, J., Wang, X., and Glindemann, D.: Tropospheric phosphine and its sources in coastal Antarctica, Environ. Scie. Technol., 40, 7656-7661, 2006.

Zoller, W. H., Gladney, E., and Duce, R. A.: Atmospheric concentrations and sources of trace metals at the South Pole, Science, 183, 198-200, 1974. 